\title{
Towards aflatoxins: a formal synthesis of aflatoxin B2
}

\author{
Stephen A. Eastham ${ }^{\text {a }}$, Steven P. Ingham ${ }^{\text {a }}$, Michael R. Hallett ${ }^{\mathrm{a}}$, John Herbert ${ }^{\mathrm{b}}$, Andrea Modi ${ }^{\mathrm{a}}$, \\ Timothy Morley ${ }^{\mathrm{a}}$, James E. Painter ${ }^{\mathrm{a}}$, Prakash Patel ${ }^{\mathrm{c}}$, Peter Quayle ${ }^{\mathrm{a}, *}$, Dean C. Ricketts ${ }^{\mathrm{a}}$, \\ James Raftery ${ }^{a}$
}

${ }^{a}$ School of Chemistry, University of Manchester, Manchester M13 9PL, UK

b Sanofi-Synthélabo, Willowburn Avenue, Alnwick, Northumberland NE66 2JH, UK

${ }^{\mathrm{c}}$ Zeneca Specialties, PO Box 42, Hexagon House, Blackley, Manchester M9 8ZS, UK

Received 16 July 2007; received in revised form 26 October 2007; accepted 26 October 2007

In memoriam J. Malcolm Bruce (5/10/32-15/5/2007). A true gentleman, chemist and selfless member of the University of Manchester

\begin{abstract}
The development of a formal synthesis of aflatoxin B2 is described, which utilizes a Dötz benzannulation reaction as a key step. (C) 2007 Elsevier Ltd. All rights reserved.
\end{abstract}

Keywords: Dötz; Benzannulation; Aflatoxin; Silatropic; Metallation

\section{Introduction}

A colleague once remarked ${ }^{1}$ that the initiation of an independent research career may best be described as "the best and worst of times", which is a sentiment I can wholeheartedly attest to. As a fledgling academic I was intrigued by the work of Schrock ${ }^{2}$ on the then emerging chemistry of nucleophilic, Tebbe-type, carbene complexes and decided to utilize these intermediates in an approach to the molecule of the moment $-\operatorname{taxol}^{3}$ - unfortunately none of this work came to fruition and has never seen the light of day.

Having realized that taming such chemistry was just too much for a first year graduate student we decided to change the metal and investigate, for a couple of months at least, the chemistry of the better behaved, and more user friendly chromium-carbene complexes. ${ }^{4}$ This paper describes the work leading to the formal synthesis of aflatoxin B2, which utilizes a Dötz benzannulation in the synthesis of the highly functionalized aromatic core of the natural product.

\footnotetext{
* Corresponding author. Tel.: +44 161275 4619; fax: +44 1612754598.

E-mail address: peter.quayle@manchester.ac.uk (P. Quayle).
}

\section{Results and discussion}

Believing, at the time (1988), that the Dötz reaction, ${ }^{5}$ Scheme 1, was ripe for exploitation our attention focused in gaining a footing in this area. Our initial synthetic target was to be $12-O$-methyl royleanone, $\mathbf{1}$, a member of the abietane family of diterpenes, which has a broad range of biological activity.

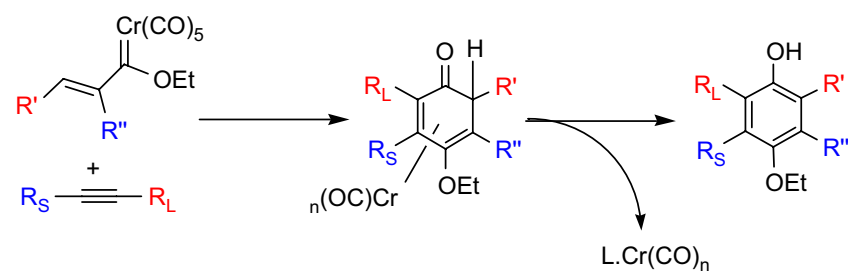

Scheme 1. The Dötz benzannulation reaction. ${ }^{5}$

Gratifyingly the key reaction in our approach to $\mathbf{1}$, the benzannulation reaction between the Fischer carbene complex 2 and the disubstituted alkyne $\mathbf{3}$, proceeded without incident and afforded, after mild oxidative work-up, the target $\mathbf{1}$ in good overall yield, Scheme $2{ }^{6}$ Crucially the regiochemical 


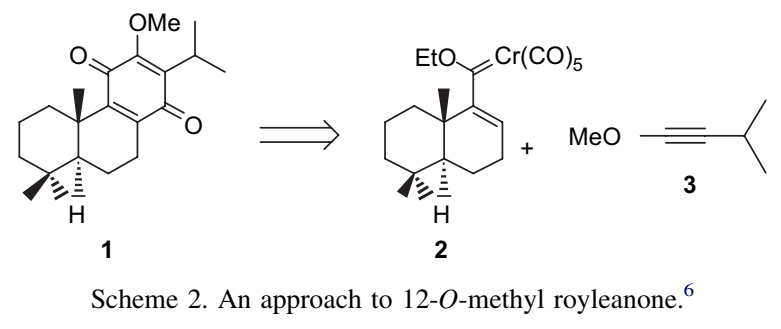

outcome of this reaction appeared to be in accord with the paradigm enunciated by Dötz ${ }^{7}$ and Wulff. ${ }^{8}$ Previously these groups had clearly shown that the differing steric bulk of the substituents on the alkyne had a controlling effect on the regiochemistry of its incorporation into the benzannulated product (i.e., $i-\operatorname{Pr}\left[\mathrm{R}_{\mathrm{L}}\right]>\mathrm{OMe}\left[\mathrm{R}_{\mathrm{S}}\right]$ ), Scheme 1.

Encouraged by this early result we wished to apply the Dötz reaction to the synthesis of heterocyclic systems such as aflatoxin B2 (4) and cryptosporin, which, by necessity would utilize heterosubstituted $\alpha, \beta$-unsaturated Fischer carbene complexes in the key benzannulation step, Scheme 3 . Somewhat naively we proposed a convergent strategy to the synthesis of aflatoxin B2 (4), a representative member of the furo[2,3-b] benzofuran ${ }^{9}$ family of mycotoxins, which was to involve a benzannulation reaction between the carbene complex 5 and the functionalized acetylene $\mathbf{6}$.

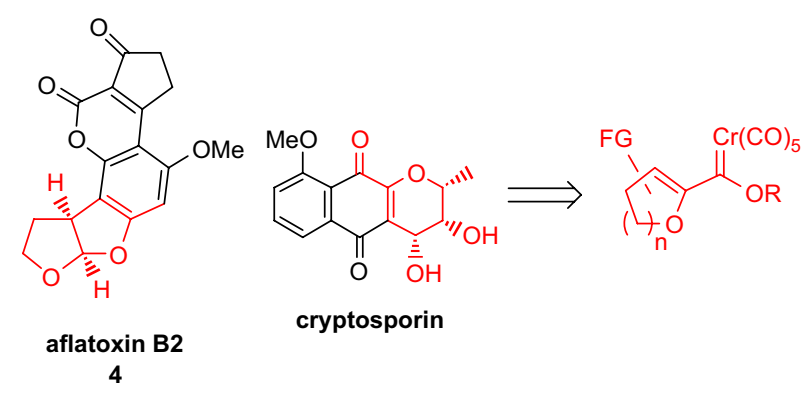

Scheme 3. Dötz reaction-potential synthetic applications.

In keeping with our earlier work on royleanone ${ }^{6}$ we presumed that the methoxy substituent of $\mathbf{6}$ would act as the 'small' group and be incorporated proximal to the alkoxy group of the carbene complex 5 during the pivotal benzannulation step. That said we were also confident ${ }^{10,11}$ that ester $\mathbf{7}$, the initial product of the benzannulation sequence, would cyclize to the lactone $\mathbf{8}$, thereby providing a route to the desired target 4, Scheme 4.

At the outset of this investigation we noted that although furan-derived Fischer carbene complexes had been utilized in Dötz reactions dihydropyranylcarbene complexes had only received limited scrutiny ${ }^{11,12}$ and there were no reports of the application of dihydrofuranylcarbene complexes in such reactions. Similarly, the preparation and downstream chemistry of furo[2,3-b]furan-2-yl carbene complexes such as $\mathbf{5}$ was without literature precedent, a methodological challenge, which, in fact, provided the initial impetus for conducting this investigation. Due to the lack of literature precedent in this area we therefore set about the synthesis of the parent

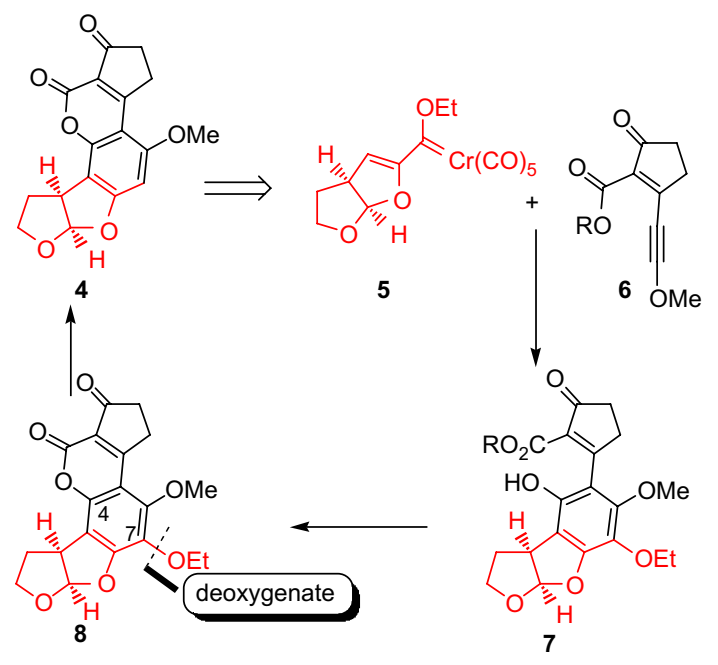

Scheme 4. Initial route to aflatoxin B2.

carbene complex 9 with a view to validating its utility in Dötz benzannulation sequences. Unfortunately lithiation of dihydrofuran using Boeckmans's ${ }^{13 a}$ procedure followed by the standard Fischer ${ }^{13 \mathrm{~b}}$ protocol afforded the carbene complex $\mathbf{9}$, which rapidly decomposed on attempted isolation. As the instability of $\mathbf{9}$ precluded its purification we set about evaluating the use of the crude carbene complex in Dötz benzannulation reactions. Much to our dismay this particular complex proved to be an inefficient partner in such reactions, resulting in the isolation of only trace quantities of the desired benzannulated products even after extensive experimentation and variation of reaction conditions (DSA absorption techniques, ${ }^{14}$ etc.), Scheme 5. This unfortunate set of observations was most disconcerting and led us conclude that, for some reason, the dihydrofuranyl complex 9 was innately unstable, a realization, which led us to consider the development of a surrogate for this particular system.

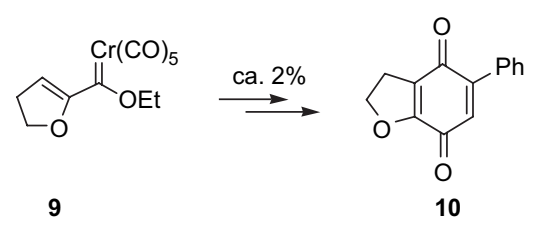

Scheme 5. Methodological limitation.

On considering the mechanism of the Dötz reaction, ${ }^{5}$ we proposed that the introduction of a nucleofugal group onto the $\beta$-carbon of the carbene complex could have a number of potential (beneficial) effects such as: (i) increasing the acidity of the $\alpha-\mathrm{CH}$ in the starting material thereby facilitating initial metallation prior to carbene synthesis; (ii) provide steric/ electronic stabilization of the carbene complex once formed and (iii) act as a leaving group in the final aromatization step $^{15}$ of the benzannulation sequence, Scheme 6 . In the intervening years we have investigated this hypothesis, ${ }^{11,16}$ and have shown that a variety of $\beta$-substituents $\left(\mathrm{Cl}, \mathrm{SPh}, \mathrm{SO}_{2} \mathrm{Ph}\right.$ 


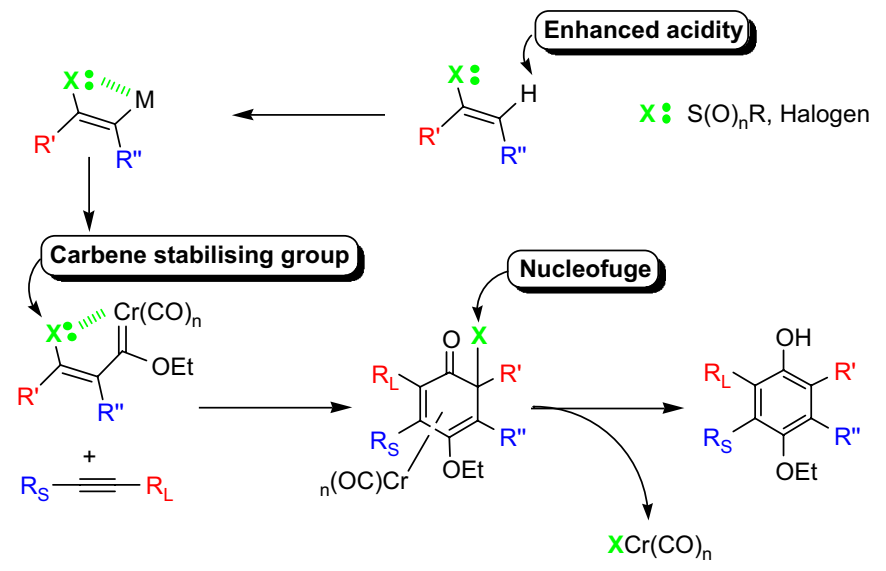

Scheme 6. 'Second generation' Dötz reactions.

and $\mathrm{F}$ ) could be introduced into a range of unsaturated carbene complexes (compounds 11-18, Fig. 1).

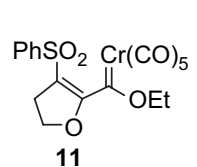<smiles>CCOC(=O)C(OCC)=C1OCCC1Sc1ccccc1</smiles><smiles>CCOc1c(-c2ccccc2)sc2c1OCC2</smiles><smiles>O=C([O-])C(=O)N1CCCC1</smiles><smiles></smiles><smiles>CCOC(=C(C(=O)OC)C(C)(C)C)c1ocnc1Cl</smiles>

$$
14
$$

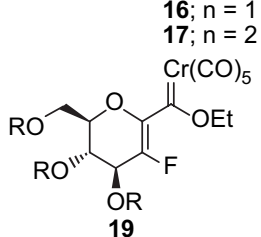

Figure 1. Heterofunctionalized Fischer carbene complexes.

By and large, the presence of these substituents had the desired effect both in terms of stabilization of the carbene complex yet facilitating our newly devised 'second generation' Dötz reaction. Although these studies proved interesting in terms of developing the co-ordination ${ }^{16,17}$ chemistry of chromium and ultimately provided new methodology for the functionalization of carbohydrates ${ }^{18}$ it was merely diversionary in terms of developing a strategy towards the synthesis of aflatoxins. Having lost sight of this objective for some time we decided therefore to re-investigate our synthetic strategy to this particular class of natural products. Once again, however, we were thwarted in our attempts to make headway towards this goal as we discovered that attempted benzannulation of the carbene complex 16 with either of the functionalized alkynes ${ }^{19} \mathbf{2 0}, \mathbf{2 2}$ and $\mathbf{2 4}$ generated complex reaction mixtures, which were apparently devoid of the tetracyclic lactones $\mathbf{2 1}, \mathbf{2 3}$ or $\mathbf{2 5}$, respectively, Scheme 7.

Not wholly dismayed by this setback we decided to modify our approach so that, in the first instance at least, we would

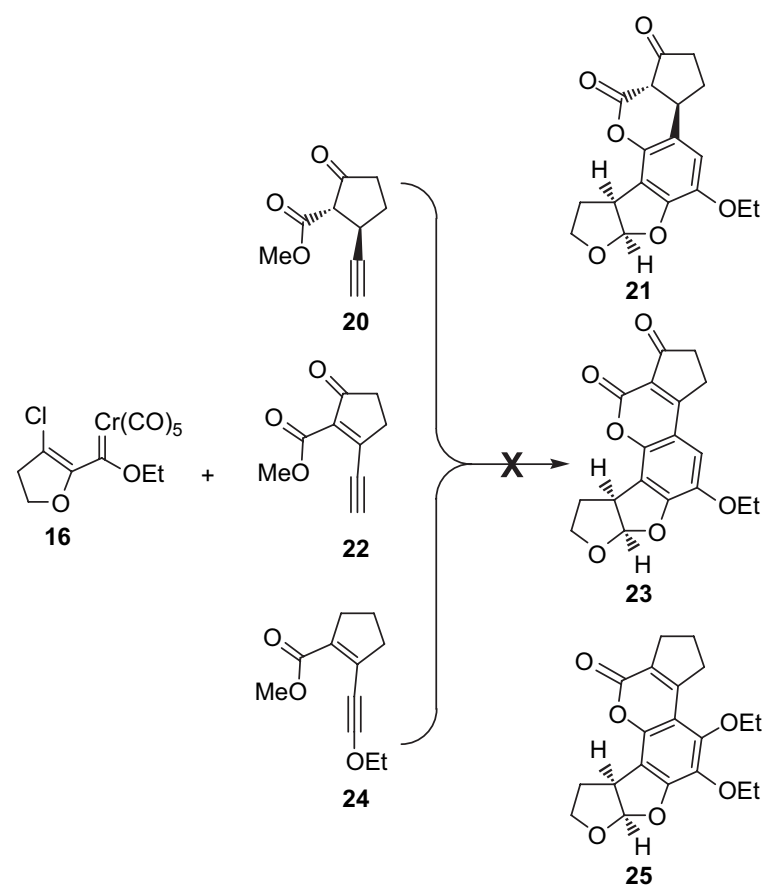

Scheme 7. Aflatoxin B2-initial model studies.

aim for the synthesis of the phenol 26, which had previously been utilized ${ }^{20}$ in the synthesis of $\mathbf{4}$. We envisaged that $\mathbf{2 6}$ would be accessible from the Dötz reaction between the furo[2,3-b]furan-2-yl carbene complexes 5 (or 27) and the functionalized alkyne $\mathbf{2 8}$.

Again, while regiochemical issues arising from the use of oxygenated acetylenes in the Dötz reaction have not been extensively investigated we were confident, from the meager literature precedents ${ }^{21}$ and from our own studies, ${ }^{6,11}$ that this particular benzannulation reaction would result in the incorporation of the methoxy substituent at $\mathrm{C} 6$ in $\mathbf{2 6}$ (i.e., $\mathrm{R}_{3} \mathrm{Si}$ $\left.\left[R_{L}\right]>\mathrm{OMe}\left[\mathrm{R}_{\mathrm{S}}\right]\right)$. Given the much simpler structure of the alkyne $\mathbf{2 8}$ when compared to $\mathbf{2 0 , 2 2}$ and $\mathbf{2 4}$ we were confident that this analysis would provide a viable solution to the apparent limitations of the benzannulation methodology, Scheme 8. What was not so clear at this juncture was the manner in which<smiles>COc1cc2c(c3oc(=O)c4c(c13)CCC4=O)[C@H]1CCO[C@@H]1[C@H](C)O2</smiles>

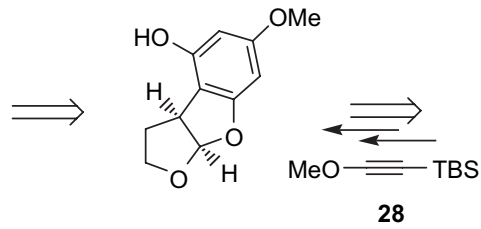

26

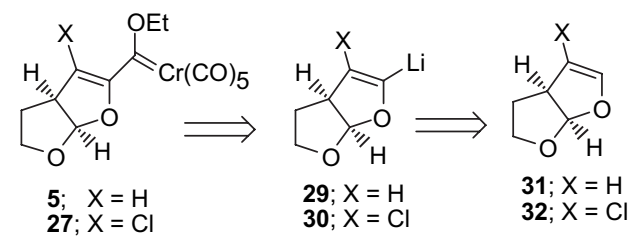

Scheme 8. Aflatoxin B2-revised strategy. 
the two phenolic oxygens at $\mathrm{C} 4$ and $\mathrm{C} 7$ could be differentiated in order to permit selective deoxygenation at $\mathrm{C} 7$. The carbene complexes 5 and $\mathbf{2 7}$ were to be prepared from the furo[2,3b] furans $\mathbf{3 1}$ and 32, respectively, using standard BoeckmanFischer methodology. ${ }^{13}$ We proposed that the enol ether $\mathbf{3 1}{ }^{22}$ could be prepared in a five step sequence from dihydrofuran as outlined in Scheme 9. This sequence necessitated the use of a Bamford-Stevens reaction in the final step, a reaction, which surprisingly has little precedent for the synthesis of cyclic enol ethers. ${ }^{23}$ Haloethetherification ${ }^{24}$ of dihydrofuran with propargyl alcohol in the presence of NIS or NBS afforded the trans-haloethers $\mathbf{3 3}$ and $\mathbf{3 6}$ in near quantitative yield.

Unfortunately cyclization ${ }^{25}\left(\mathrm{Bu}_{3} \mathrm{SnH}, \mathrm{AIBN}, \mathrm{PhH}\right)$ of the iodide $\mathbf{3 3}$ in our hands proved problematical as variable quantities (up to $40 \%$ isolated yield) of the vinyl iodides $\mathbf{3 4}_{\boldsymbol{E}, \boldsymbol{Z}}$ were also generated via a competing atom transfer cyclization reaction. Gratifyingly, however, radical cyclization of $\mathbf{3 6}$ using Okabe's ${ }^{26}$ procedure afforded the exocyclic alkene ${ }^{25}$ in reproducible yields of ca. $62 \%$ on a $260 \mathrm{mmol}$ scale, Scheme 9 . This cobalt catalyzed cyclization reaction proved to be very robust and proceeds without the generation of large quantities

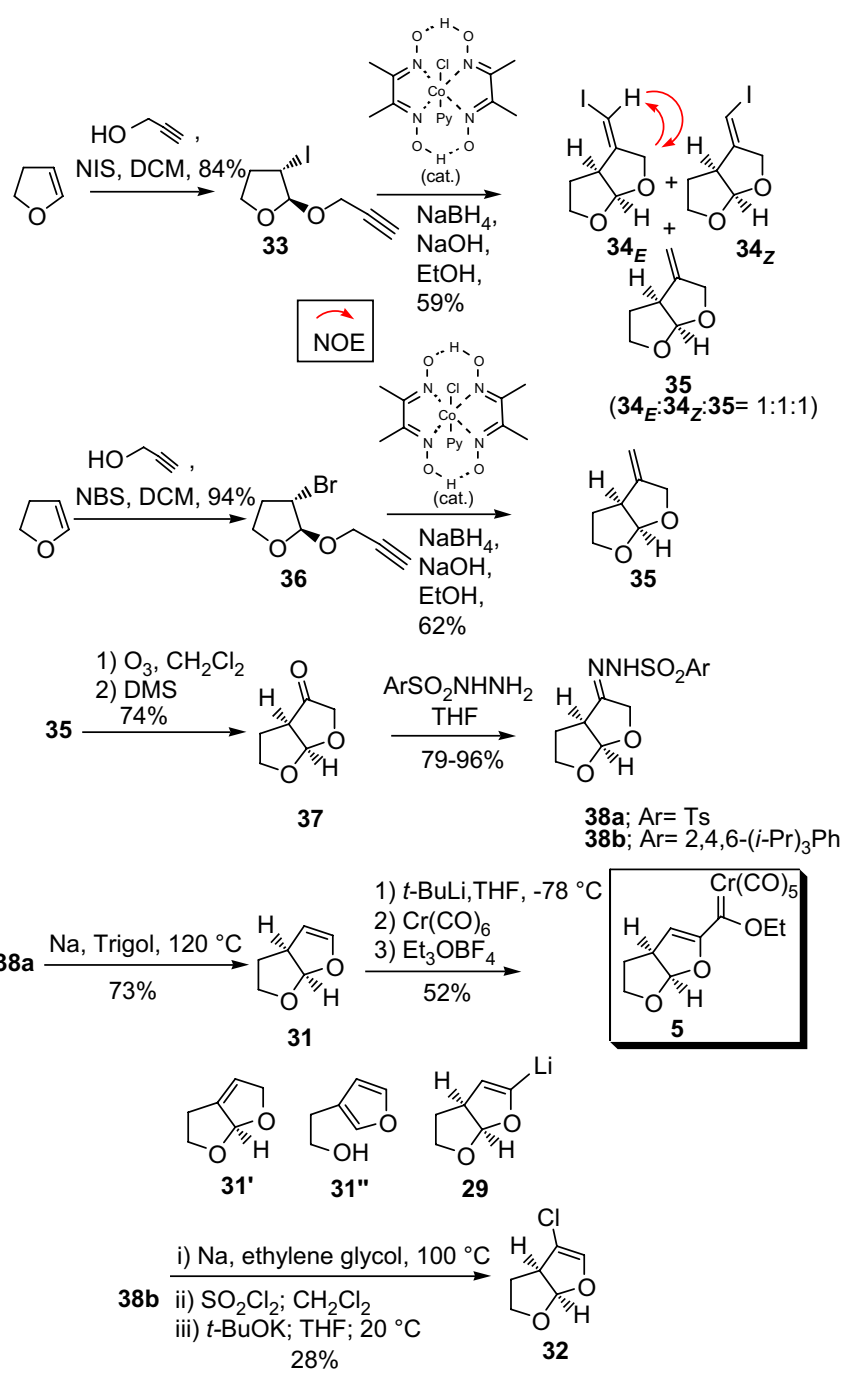

Scheme 9. Aflatoxin B2-synthesis of carbene complex. of tin residues, which is an unfortunate feature of TBTH methodology when conducted on a preparative scale. Ozonolysis of $35\left(\mathrm{O}_{3}, \mathrm{CH}_{2} \mathrm{Cl}_{2},-78^{\circ} \mathrm{C}\right)$ followed by reductive work-up $\left(\mathrm{Me}_{2} \mathrm{~S}\right)$ was routinely carried out on a $100 \mathrm{mmol}$ scale and afforded the ketone $37,{ }^{22 \mathrm{c}}$ a low melting solid, in $74 \%$ isolated yield. Conversion of $\mathbf{3 7}$ to the hydrazones $\mathbf{3 8} \mathbf{a}$ and $\mathbf{3 8} \mathbf{b}$ (both as a 1:1 mixture of geometrical isomers) and hence to the enol ether 31 was next investigated. After careful optimization it was found that the Bamford-Stevens reactions of $\mathbf{3 8 a}, \mathbf{b}$ were best carried out by mild thermolysis of their respective sodium salts in either ethylene glycol or trigol under reduced pressure $(20 \mathrm{mmHg})$. Under these conditions the enol ether $\mathbf{3 1}$ could simply be collected in a cardice trap on a preparative scale. The enol ether $\mathbf{3 1}$ generated in this way was isolated in an essentially pure state and was devoid of any trace of the alternate double bond isomer $\mathbf{3 1}^{\prime}$ or furan $\mathbf{3 1}^{\prime \prime}$. Although the Bamford-Stevens reaction of the hydrazone $\mathbf{3 8 b}$ afforded enol ether 31 in higher yields (77\%) on a small scale $(8.9 \mathrm{mmol})$ this marginally greater efficiency was not translated to preparative-scale experiments where both substrates gave essentially the same yield. With a reliable route to the enol ether $\mathbf{3 1}$ in hand its conversion to the Fischer carbene complexes $\mathbf{5}$ and $\mathbf{2 7}$ was next pursued. As conversion of the enol ether $\mathbf{3 1}$ to the vinyl chloride $\mathbf{3 2}$, the precursor to the chlorocarbene complex 27, proved to be too low-yielding (28\%) to be preparatively useful the synthesis of $\mathbf{2 7}$ was not pursued further and our efforts focused upon the synthesis of the complex $\mathbf{5}$.

To our delight the direct metallation $\left({ }^{t} \mathrm{BuLi}, 1.1\right.$ equiv, THF, $-78{ }^{\circ} \mathrm{C}, 15 \mathrm{~min}$ and then at $20^{\circ} \mathrm{C}$ for $30 \mathrm{~min}$ ) of enol $\mathbf{3 1}$ to the organolithium 29 proceeded smoothly as did its subsequent conversion to the carbene complex $\mathbf{5}$, Scheme 8. Complex 5 was isolated as a deep red stable solid, in 52\% yield after chromatography and recrystallization, an outcome, which was wholly unexpected when compared to our initial experience with the parent carbene complex 9 . We can only presume, at this stage, that the presence of the additional oxygen, which is embedded into the furo[2,3- $b$ ] furanyl ring system plays an important (electronic) role in stabilizing this particular carbene complex.

Given that we now had access to multigram quantities of carbene complex 5 its benzannulation reaction with the oxygenated acetylene $\mathbf{2 8}$ could be attempted. The alkyne $\mathbf{2 8}$ was conveniently prepared from chloroacetaldehyde dimethyl acetal using a modification of the method reported by Raucher. ${ }^{27}$ Exposure of the acetal to LDA ( 3 equiv; $-78^{\circ} \mathrm{C}$ to $\mathrm{rt}, 4 \mathrm{~h}$ ) followed by the addition of TBSCl (1 equiv) afforded the acetylene $\mathbf{2 8}$ in reproducible yields of $22 \%$ yield after Kügelrohr distillation. It should be pointed out that monitoring of this reaction is important as premature quenching the reaction too early with the TBSCl led to the isolation of the vinyl silane $\mathbf{3 9}$ as the sole product ${ }^{28}$ (35\% yield after Kügelrohr distillation), Scheme 10.

At this stage we were now ready to attempt the key Dötz reaction and were gratified to find that exposure of the complex 5 to the acetylene 28 ( 2.5 equiv) in THF at $80^{\circ} \mathrm{C}$ for $2 \mathrm{~h}$ resulted in the complete consumption of the complex 5 


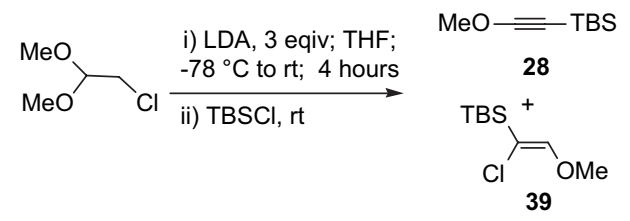

Scheme 10. Synthesis of alkyne 28 .

and afforded the phenol $\mathbf{3 3}$ in $31 \%$ yield after column chromatography. The regiochemical outcome of this benzannulation reaction is in keeping with previous methodological studies ${ }^{6,11}$ and was substantiated by spectroscopic studies and further chemical manipulation. Hence desilylation of $\mathbf{4 0}$ (TBAF, THF, $20{ }^{\circ} \mathrm{C}$ ) afforded the phenol $\mathbf{4 4}$ whose ${ }^{1} \mathrm{H}$ NMR spectrum was sufficiently dispersed to enable NOE experiments to be carried out, Scheme 11. Of note is the observation that we were unable to detect any of the alternate regioisomeric phenol 41 in the crude reaction mixture of this Dötz reaction but were able to isolate variable quantities ${ }^{29}$ of the cyclopentenones $\mathbf{4 2}$ (ca. 1\%) and $\mathbf{4 3}(<1 \%)$, Scheme 11.

The product distribution of this reaction was found to be quite sensitive to the reaction conditions employed ${ }^{29}$ (solvent polarity, temperature and additives) but fortuitously those used in the first attempt proved to be optimal and reproducible in

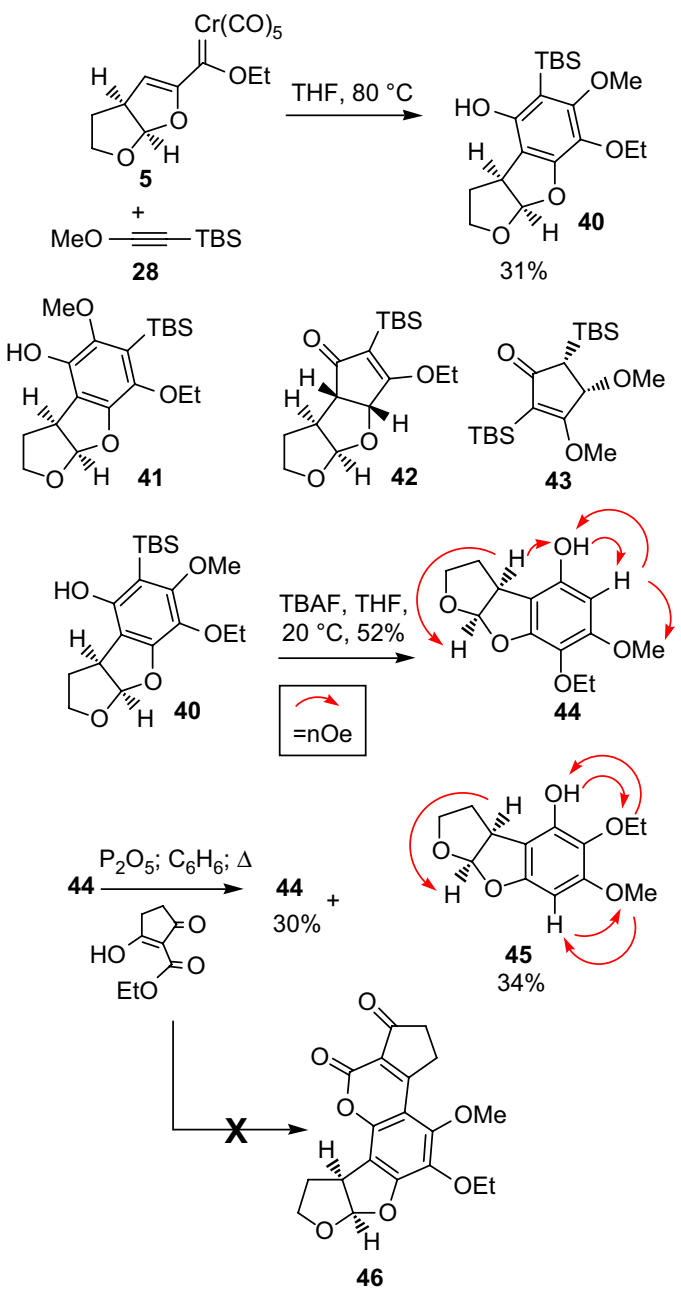

Scheme 11. Aflatoxin B2-revised benzannulation sequence.

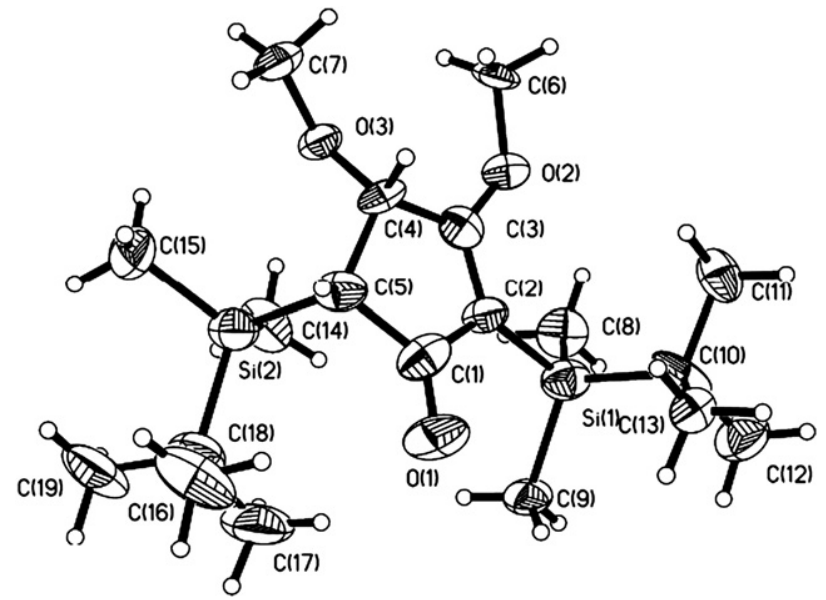

Figure 2. X-ray structure of cyclopentenone $\mathbf{4 3}$.

terms of phenol 40. Structural assignments in the case of $\mathbf{4 2}$ were based upon detailed spectroscopic analysis whilst the structure of $\mathbf{4 3}$ was unambiguously established by way of Xray crystallography, Figure 2. At this juncture we decided, by way of a model study, to functionlize the free phenolic$\mathrm{OH}$ group of 44. Unfortunately attempted cyclization of the phenol 44 into lactone 46, using a classical variant of the von Pechmann cyclization reaction, ${ }^{30}$ resulted in the re-isolation of starting material $\mathbf{4 4}$ (30\% yield) together with the rearranged phenol 45 (34\% yield), Scheme 11. We suspect that this equilibration occurred via the reversible ring openingtrapping of the acetal moiety, a reaction, which was unforeseen but not without precedence in this system. ${ }^{20 \mathrm{~h}}$ Again NOE studies proved invaluable in providing corroborating evidence for this structural assignment as both the ${ }^{1} \mathrm{H}$ NMR and ${ }^{13} \mathrm{C}$ NMR spectra of $\mathbf{4 4}$ and $\mathbf{4 5}$ were almost identical.

As we were unable to detect the formation of desired lactone 46, Scheme 11, we obviously had to rethink our strategy for the selective deoxygenation of substrates such as $\mathbf{4 4}$. We decided therefore to attempt regioselective protection hydroquinone $\mathbf{4 8}$ under less forcing conditions. However, although hydroquinone $\mathbf{4 8}$ could be prepared from phenol $\mathbf{4 4}$ in a simple two step oxidation-reduction sequence this route was hampered by the instability of hydroquinone $\mathbf{4 8}$ and failed to provide a practical solution to this problem, Scheme 12. At this stage, and quite fortuitously, we noted a marked solvent
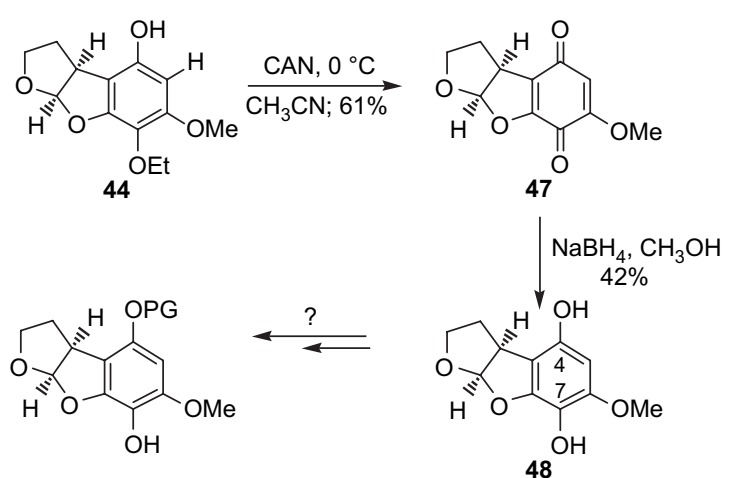

Scheme 12. Planned protection of diol 48. 
effect in the benzannulation reactions involving carbene complex $\mathbf{5}$ and alkyne 28, an observation, which ultimately was to provide a practical solution for the regioselective deoxygenation of $\mathbf{4 0 .}$

In this study, Scheme 13, we found that conducting the Dötz reaction in toluene rather than in THF, which in our hands is usually the solvent of choice for such reactions, resulted in the isolation of the silyl ether $\mathbf{4 9}$ as the major product rather than the phenol $\mathbf{4 0}$.

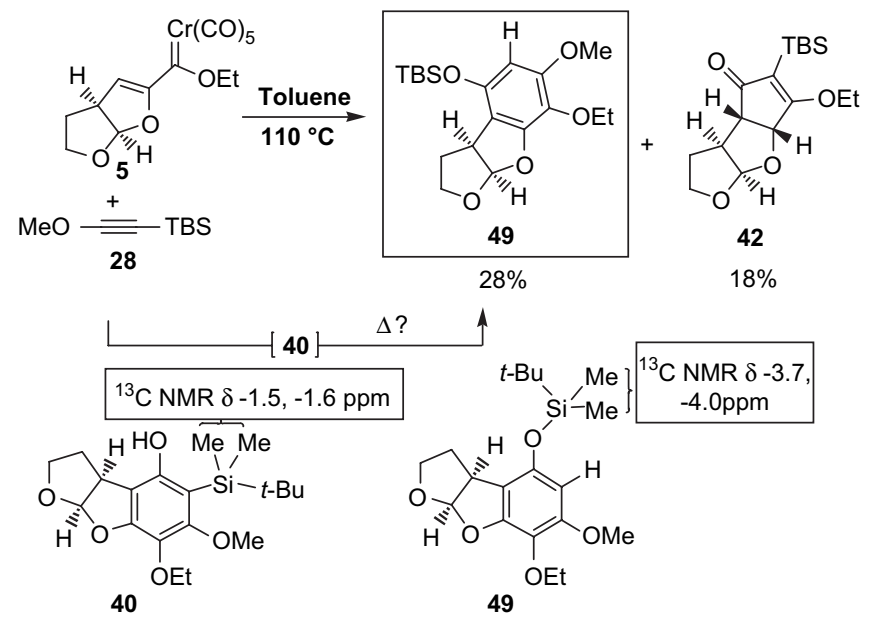

Scheme 13. A fortuitous result.

We presume that $\mathbf{4 2}$ arose via a formal 1,3-silatropic rearrangement ${ }^{31}$ of the initial product $\mathbf{4 0}$ under these more forcing conditions. If this were the case, and was a reaction, which proved to be general, ${ }^{32}$ then it could provide a deceptively simple solution to the selective protection of the $\mathrm{C} 4$ hydroxyl group in substrates such as $\mathbf{5 1}$, Scheme 14. This hypothesis was readily tested and resulted in a simple three step sequence for the conversion of $\mathbf{4 0}$ into $\mathbf{5 2}$, Scheme 14. In practise this entailed oxidation of the phenol $\mathbf{4 0}$ to the
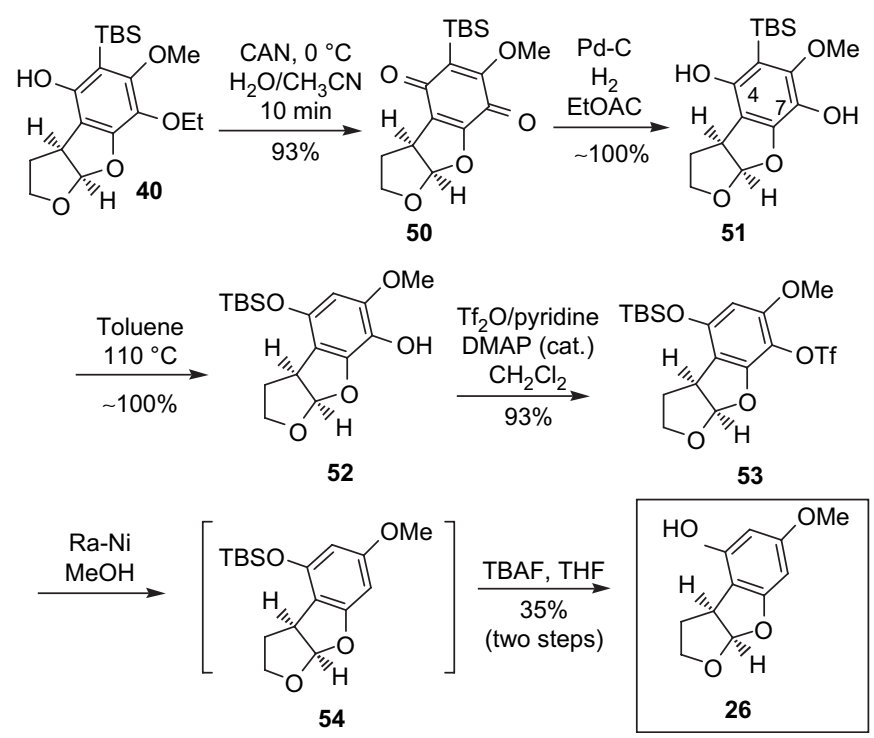

Scheme 14. Deoxygenation at C7-completion of route. quinone $\mathbf{5 0}\left(\mathrm{CAN}, \mathrm{CH}_{3} \mathrm{CN} / \mathrm{H}_{2} \mathrm{O}\right)$, reduction of $\mathbf{5 0}$ to the hydroquinone $51\left(\mathrm{H}_{2}-\mathrm{Pd} / \mathrm{C}\right)$ followed by rearrangement to $\mathbf{5 2}$.

Rather pleasingly the 1,3-silatropic migration (51 to 52) occurs essentially quantitatively upon mild thermolysis in toluene $\left(110^{\circ} \mathrm{C}, 1 \mathrm{~h}\right)$ and is apparently wholly regioselective. The overall yield for three step sequence from $\mathbf{4 0}$ to $\mathbf{5 2}$ was pleasingly high (93\%); regiochemical issues in the case of 52 were again addressed using NOE difference measurements, Scheme 15. Whilst there have been sporadic reports of similar silicon migrations in Dötz benzannulation reactions ${ }^{31}$ its application to the in situ, regioselective, protection of hydroquinones (as opposed to monoalkyl derivatives ${ }^{31}$ ) has not to our knowledge been previously reported. Presumably, the rearrangement of $\mathbf{5 1}$ into $\mathbf{5 2}$ proceeds via the intermediacy of the tautomeric cyclohexadienone $\mathbf{5 1}$, followed by a formal 1,3-silatropic shift, the driving force for the reaction being the formation of a strong $\mathrm{O}-\mathrm{Si}$ bond. ${ }^{32}$

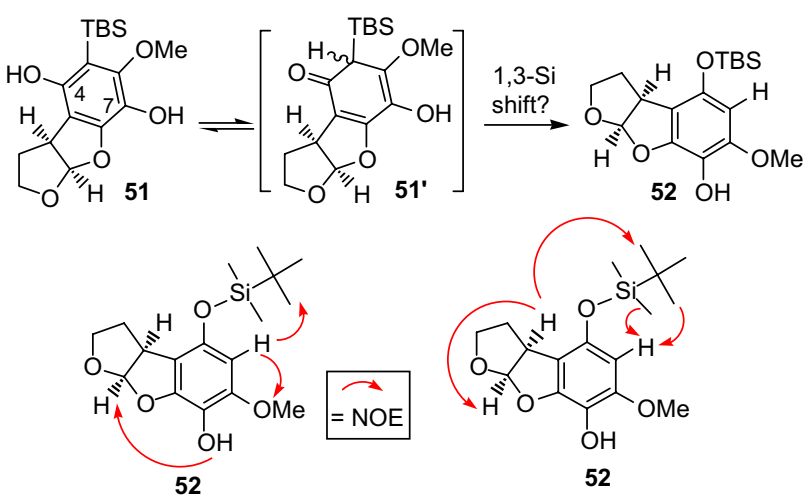

Scheme 15. Mechanism for 1,3-Silatropic rearrangement.

Having developed a facile route to the preparation of the protected hydroquinone $\mathbf{5 2}$ its deoxygenation at $\mathrm{C} 7$ was next investigated. Most frustratingly deoxygenation of $\mathbf{5 2}$ proved to be less than straightforward. For example, whilst reduction of 53 using Sáa's ${ }^{33}$ modification of Cacchi's procedure ${ }^{34}$ $\left(\mathrm{PdCl}_{2}\right.$, dppp, $\left.\mathrm{HCO}_{2} \mathrm{H}, \mathrm{Bu}_{3} \mathrm{~N}, \mathrm{DMF}, 80^{\circ} \mathrm{C}\right)$ did in fact effect deoxygenation with concomitant in situ deprotection to the desired intermediate 26, the product was contaminated with $\mathrm{N}, \mathrm{N}$-dibutylformamide, which could only be removed by recrystallization resulting in a low overall isolated yield of pure material $(11 \%)$. Fortunately Noland ${ }^{20 b}$ has described a modified procedure for this type of reduction involving the use of Raney nickel. Hence exposure of $\mathbf{5 3}$ to Raney nickel followed by desilylation (TBAF, THF, $20^{\circ} \mathrm{C}$ ) of the intermediate silylether $\mathbf{5 4}$ afforded the desired phenol 26 in $35 \%$ isolated yield over the two steps. The phenol $\mathbf{2 6}$ prepared in this manner was identical to that described by Rapoport ${ }^{20 \mathrm{c}}$ and Noland ${ }^{20 \mathrm{~b}}$ and therefore constitutes a formal synthesis of the natural product.

In conclusion, we have demonstrated that the Dötz reaction between a furo[2,3-b]furanyl carbene complex and a silylated acetylene provides ready access to a pivotal intermediate for the synthesis of aflatoxin B2. Although this reaction proceeds in only moderate yield $(31 \%)$ its convergent nature, leading to 
the synthesis of a highly functionalized intermediate, is noteworthy. The silicon substituent fulfils two roles by controlling the regiochemistry of the initial Dötz reaction and providing a facile means by which the selective protection-deoxygenation of a hydroquinone intermediate can be achieved. This study also underscores the potential limitations of the Dötz reaction when applied to more sterically congested or electronically mismatched alkyne partners. $\alpha, \beta$-Unsaturated Fischer carbene may be innately unstable and preclude their use in the Dötz reaction, a situation that can sometimes be remedied by the temporary introduction of a stabilizing substituent. The facile lithiation of the 2,3,3a,6a-tetrahydrofuro[2,3-b]furan may be of potential utility for the synthesis of other furo[2,3- $b]$ furan-containing natural products.

\section{Experimental}

\subsection{General}

All reactions unless stated otherwise were carried out under a nitrogen atmosphere. Tetrahydrofuran and diethyl ether were dried by distillation from sodium-benzophenone; toluene, dichloromethane and acetonitrile were dried by distillation from calcium hydride; dimethylformamide was dried over $4 \AA$ molecular sieves. All other chemicals were purified using standard procedures as required. Thin layer chromatography (TLC) was carried out on Merck silica gel $\mathrm{F}_{254} 0.255 \mathrm{~mm}$ plates, and spots were visualised, where appropriate, by UV fluorescence at 254 or $297 \mathrm{~nm}$ or by spraying with phosphomolybdic acid in ethanol, iodine or vanillin in ethanol/sulfuric acid. Flash column chromatography was performed using Merck Kieselgel 60 (230-400 mesh) silica. The purification of carbenes was carried out by flash column chromatography under a nitrogen atmosphere; solvent and silica was degassed prior to use. IR spectra were recorded on an AT1 Mattson Genesis series FTIR spectrometer and are given in $\mathrm{cm}^{-1}$, points of maximum absorption $\left(\nu_{\max }\right)$ are recorded with the strength of absorption being quoted as strong (s), medium (m), weak (w) and broad (br). ${ }^{1} \mathrm{H}$ NMR spectra were recorded on a Varian AC 300E NMR spectrometer operating at $300 \mathrm{MHz} .{ }^{13} \mathrm{C} \mathrm{NMR}$ spectra were recorded on a Varian AC 300E NMR spectrometer operating at $75 \mathrm{MHz}$. All chemical shifts are reported in parts per million downfield from tetramethylsilane. Peak multiplicities are denoted by s (singlet), d (doublet), $\mathrm{t}$ (triplet), $\mathrm{q}$ (quartet) and $\mathrm{m}$ (multiplet) with coupling constants $(J)$ given in hertz. Mass spectra were recorded on a Fisons VG Trio 2000 for (EI) electron impact and chemical ionization (CI) conditions. Electrospray (ES) spectra were recorded on a Micromass Platform. Accurate mass measurements were recorded on a Kratos Concept mass spectrometer. Melting points were recorded on a Reichert heated-stage microscope and are uncorrected. Microanalyses were performed in the Microanalytical Laboratory at the School of Chemistry, University of Manchester. X-ray data measurements were made on a Rigaku AFC5R diffractometer with graphite monochromated Mo $\mathrm{K} \alpha$ radiation. Dr J. Raftery should be consulted concerning the X-ray structure of compound 43. On occasion the ${ }^{1} \mathrm{H}$
NMR spectra of carbene complex $\mathbf{5}$ proved to be quite broad, presumably due to the presence of trace amounts of paramagnetic material. However, addition ${ }^{35}$ of a very small quantity of the mild reducing agent $\mathrm{Co}(\mathrm{Cp})_{2}$ to the NMR sample generated sharp, well resolved, spectra.

\subsection{1. $\left(2 S^{*} R^{*}, 3 R^{*} S^{*}\right)$-3-Bromo-2-(prop-2yn-1-yloxy)- tetrahydrofuran, $36^{22 c}$}

Dihydrofuran $(16 \mathrm{~mL}, 211 \mathrm{mmol})$ and propargyl alcohol (24.5 mL, $421 \mathrm{mmol})$ were dissolved in dichloromethane $(150 \mathrm{~mL})$ and the solution cooled to $-15^{\circ} \mathrm{C}$. Freshly recrystallized $N$-bromosuccinimide $(45.0 \mathrm{~g}, 252.8 \mathrm{mmol})$ was added portionwise over $30 \mathrm{~min}$ to the solution, which was allowed to warm to room temperature and stirred for a further $5 \mathrm{~h}$. The resulting solution was washed with brine $(60 \mathrm{~mL})$, dried $\left(\mathrm{MgSO}_{4}\right)$ and concentrated in vacuo. Purification of the crude oil by column chromatography (flash silica, 7\% EtOAc/petrol) afforded the title compound as a colourless oil (40.5 g, 94\%). $\nu_{\max }(\mathrm{film}) / \mathrm{cm}^{-1} 3292$ (s), $2930(\mathrm{~m}), 2900$ (s), 1482 (s), 1440 (s); ${ }^{1} \mathrm{H} \mathrm{NMR}\left(300 \mathrm{MHz}, \mathrm{CDCl}_{3}\right) \delta 5.38(1 \mathrm{H}, \mathrm{s}, \mathrm{H}-2)$, 4.20-4.00 (3H, m, H-3, 5), 4.10-4.00 (2H, m, $\left.-\mathrm{OCH}_{2} \mathrm{C} \equiv \mathrm{H}\right)$, $2.63(1 \mathrm{H}, \mathrm{m}, \mathrm{H}-4), 2.43(1 \mathrm{H}, \mathrm{t}, J=2.5 \mathrm{~Hz},-\mathrm{C} \equiv \mathrm{CH}), 2.18$ $(1 \mathrm{H}, \mathrm{m}, \mathrm{H}-4) ;{ }^{13} \mathrm{C} \mathrm{NMR}\left(75 \mathrm{MHz}, \mathrm{CDCl}_{3}\right) \delta 106.8,78.9$, 74.6, 67.0, 53.9, 49.6, 33.6; m/z (CI) $222\left(\mathrm{MNH}_{4}^{+}, 55 \%\right) 204$ $\left(\mathrm{M}^{+}, 5 \%\right)$; found $\mathrm{MNH}_{4}^{+} 222.0133, \mathrm{C}_{7} \mathrm{H}_{9} \mathrm{O}_{2}^{79} \mathrm{Br}$ requires $\mathrm{MNH}_{4}^{+}$222.0130.

\subsection{2. (2S*R*,3R* $\left.S^{*}\right)$-3-Iodo-2-(prop-2-yn-1-yloxy)- tetrahydrofuran, $\mathbf{3 3}^{25}$}

Dihydrofuran $(2.3 \mathrm{~mL}, 31.1 \mathrm{mmol})$ and propargyl alcohol $(2.7 \mathrm{~mL}, 46.5 \mathrm{mmol})$ were dissolved in dichloromethane $(50 \mathrm{~mL})$ and cooled to $0{ }^{\circ} \mathrm{C}$. Freshly recrystallized $N$-iodosuccinimide $(7.0 \mathrm{~g}, 31.1 \mathrm{mmol})$ was then added portionwise over $30 \mathrm{~min}$ to the solution, which was allowed to warm to room temperature and stirred for a further $5 \mathrm{~h}$. The resulting solution was washed with brine $(30 \mathrm{~mL})$, dried $\left(\mathrm{MgSO}_{4}\right)$ and concentrated in vacuo. Purification of the crude oil by column chromatography (flash silica, 10\% EtOAc/petrol) afforded the title compound as a colourless oil $(6.6 \mathrm{~g}, 84 \%) . \nu_{\max }(\mathrm{film}) / \mathrm{cm}^{-1}$ 3291 (s), 2949 (m), 2897 (s), 1440 (s), 1024 (s); ${ }^{1} \mathrm{H}$ NMR $\left(300 \mathrm{MHz}, \mathrm{CDCl}_{3}\right) \delta 5.50(1 \mathrm{H}, \mathrm{s}, \mathrm{H}-2), 4.02-4.34(5 \mathrm{H}, \mathrm{m}$, $\left.\mathrm{H}-3, \mathrm{H}-5,-\mathrm{CH}_{2} \mathrm{C} \equiv \mathrm{CH}\right), 2.70-2.55(1 \mathrm{H}, \mathrm{m}, \mathrm{H}-4), 2.48(1 \mathrm{H}$, $\mathrm{t}, J=2.5 \mathrm{~Hz}, \mathrm{C} \equiv \mathrm{CH}), 2.25-2.15(1 \mathrm{H}, \mathrm{m}, \mathrm{H}-4) ;{ }^{13} \mathrm{C} \mathrm{NMR}$ $\left(75 \mathrm{MHz} \mathrm{CDCl}_{3}\right) \delta 108.8,79.2,74.7,67.4,53.6,35.4,24.3$; $\mathrm{m} / \mathrm{z} 252\left(\mathrm{M}^{+}, 18 \%\right), 270\left(\mathrm{MNH}_{4}^{+}, 18 \%\right), 214(100 \%)$; found $\mathrm{M}^{+} 251.9654, \mathrm{C}_{7} \mathrm{H}_{9} \mathrm{O}_{2} \mathrm{I}$ requires $\mathrm{M}^{+} 251.9649$.

\subsection{3. (3aS* $\left.R^{*}, 6 a R^{*} S^{*}\right)-3-$ Methylenehexahydrofuro[2,3- b]furan, $3^{22 c}$}

To a solution of bromoether $36(54.50 \mathrm{~g}, 267 \mathrm{mmol})$ in ethanol $(500 \mathrm{~mL})$ was added sodium borohydride $(8.8 \mathrm{~g}$, $243 \mathrm{mmol}$ ) and sodium hydroxide $(8.4 \mathrm{~g}$, in water $20 \mathrm{~mL}$, $225 \mathrm{mmol})$. The resulting mixture was stirred until it was homogenous. Cobaloxime $(5.30 \mathrm{~g}, 13.3 \mathrm{mmol})$ was added slowly over a $10 \mathrm{~min}$ period, with gentle warming of the solution. The solution was stirred for a further $1 \mathrm{~h}$ after which time the ethanol was removed in vacuo. Water $(15 \mathrm{~mL})$ was added 
and the mixture extracted with dichloromethane $(3 \times 25 \mathrm{~mL})$, dried $\left(\mathrm{MgSO}_{4}\right)$ and concentrated in vacuo. Purification by column chromatography (flash silica 10\% EtOAc/petrol) gave the title compound as an oil $(17.4 \mathrm{~g}, 62 \%) . \nu_{\max }$ (film) $/ \mathrm{cm}^{-1} 2955$ (s), 2871 (s), 1736 (s), 1655 (m), 1462 (m); ${ }^{1} \mathrm{H}$ NMR $\left(300 \mathrm{MHz}, \mathrm{CDCl}_{3}\right) \delta 5.79(1 \mathrm{H}, \mathrm{d}, J=4.9 \mathrm{~Hz}, \mathrm{H}-6 \mathrm{a}), 5.06$ $\left(1 \mathrm{H}, \quad\right.$ app. $\left.\quad \mathrm{q}, \quad J=2.2 \mathrm{~Hz}, \quad \mathrm{C}=\mathrm{CH}_{2}\right), \quad 5.02(1 \mathrm{H}, \quad$ app. q, $\left.J=2.2 \mathrm{~Hz}, \mathrm{C}=\mathrm{CH}_{2}\right), 4.55-4.35(2 \mathrm{H}, \mathrm{m}, \mathrm{H}-2), 3.97(1 \mathrm{H}, \mathrm{td}$, $J=8.0,1.5 \mathrm{~Hz}, \mathrm{H}-5), 3.85-3.75(1 \mathrm{H}, \mathrm{m}, \mathrm{H}-5), 3.33-3.24$ $(1 \mathrm{H}, \mathrm{m}, \mathrm{H}-3 \mathrm{a}), 2.10-2.30(1 \mathrm{H}, \mathrm{m}, \mathrm{H}-4), 1.95(1 \mathrm{H}, \mathrm{dd}$, $J=12.5,5.5 \mathrm{~Hz}, \mathrm{H}-4) ;{ }^{13} \mathrm{C}$ NMR $\left(75 \mathrm{MHz}, \mathrm{CDCl}_{3}\right) \delta 150.2$, 109.6, 105.8, 72.0, 67.4, 47.2, 34.1; m/z (CI) $127\left(\mathrm{MH}^{+}\right.$, $80 \%) 144\left(\mathrm{MNH}_{4}^{+}, 100 \%\right)$; found $\mathrm{MNH}_{4}^{+} 144.1028$, $\mathrm{C}_{7} \mathrm{H}_{10} \mathrm{O}_{2}$ requires $\mathrm{MNH}_{4}^{+}$144.1024.

\subsection{4. (E)-(3aS*R*,6aR* $\left.S^{*}\right)$-3-Iodomethylenehexa- hydrofuro[2,3-b]furan, $\mathbf{3 4}_{\boldsymbol{E}}$}

Sodium borohydride $(150 \mathrm{mg}, 3.97 \mathrm{mmol})$ and cobaloxime $(161 \mathrm{mg}, 0.4 \mathrm{mmol})$ were added to ice cold ethanol $(50 \mathrm{~mL})$ containing $10 \mathrm{M}$ sodium hydroxide solution $(0.12 \mathrm{~mL}$, $4.05 \mathrm{mmol})$ and pyridine $(2.0 \mathrm{~mL})$. To this solution was added iodo ether 33 (portionwise) $(1.0 \mathrm{~g}, 3.97 \mathrm{mmol})$ in ether $(3.75 \mathrm{~mL})$. The solution was stirred for a further $1 \mathrm{~h}$ after which time the ethanol was removed in vacuo. Water $(15 \mathrm{~mL})$ was added and the mixture extracted with DCM $(3 \times 25 \mathrm{~mL})$, dried $\left(\mathrm{MgSO}_{4}\right)$ and concentrated in vacuo to afford a crude mixture of the bicyclic acetal $\mathbf{3 5}$ and a mixture of $E$ and $Z$-iodo acetals $\boldsymbol{E}, \boldsymbol{Z}-34$ in a 1:1:1 ratio (302 $\mathrm{mg}, 59 \%)$. Purification by column chromatography (flash silica 10\% EtOAc/petrol) afforded the title compound, $\mathbf{3 4}_{E}$, a straw-coloured oil, whose colour rapidly deepened on standing. $\nu_{\max }\left(\right.$ film) $/ \mathrm{cm}^{-1} 3061$ (s), 2953 (s), 2868 (s), $1639(\mathrm{~s}), 1357(\mathrm{~m}) ;{ }^{1} \mathrm{H} \mathrm{NMR}\left(300 \mathrm{MHz}, \mathrm{CDCl}_{3}\right) \delta 6.17(1 \mathrm{H}$, app. q, $J=2.1 \mathrm{~Hz}, \mathrm{H}-\mathrm{CHI}), 5.88(1 \mathrm{H}, \mathrm{d}, J=5.0 \mathrm{~Hz}, \mathrm{H}-6 \mathrm{a}), 4.40-$ $4.52(2 \mathrm{H}, \mathrm{m}, \mathrm{H}-2), 4.05(1 \mathrm{H}$, app. td, $J=8.7,2.2 \mathrm{~Hz}, \mathrm{H}-5)$, $3.86-3.78(1 \mathrm{H}, \mathrm{m}, \mathrm{H}-5), 3.30-3.22(1 \mathrm{H}, \mathrm{m}, \mathrm{H}-3 \mathrm{a})$, $2.05-2.14(1 \mathrm{H}, \mathrm{m}, \mathrm{H}-4), 2.22-2.31(1 \mathrm{H}, \mathrm{m}, \mathrm{H}-4) ; \mathrm{m} / z$ (CI) $253\left(\mathrm{MH}^{+}, 5 \%\right) 270\left(\mathrm{MNH}_{4}^{+}, 7 \%\right)$; found $\mathrm{M}^{+}$251.9653, $\mathrm{C}_{7} \mathrm{H}_{9} \mathrm{O}_{2} \mathrm{I}$ requires $\mathrm{M}^{+}$251.9649. Comparison of this data with the ${ }^{1} \mathrm{H}$ NMR spectrum of the partially separated mixture of isomers allowed us to deduce the following ${ }^{1} \mathrm{H} N M R$ for the $Z$-iodo acetal, 34 $\mathrm{Z}:{ }^{1} \mathrm{H}$ NMR $\left(300 \mathrm{MHz}, \mathrm{CDCl}_{3}\right) \delta 6.12(1 \mathrm{H}, \mathrm{q}$, $J=2.5 \mathrm{~Hz}, \mathrm{H}-\mathrm{CHI}), 5.95(1 \mathrm{H}, \mathrm{d}, J=4.8 \mathrm{~Hz}, \mathrm{H}-6 \mathrm{a}), 4.42-4.50$ $(2 \mathrm{H}, \mathrm{m}, \mathrm{H}-2), 3.96(1 \mathrm{H}, \mathrm{td}, J=9.8,2.2 \mathrm{~Hz}, \mathrm{H}-5), 3.80-3.72$ $(1 \mathrm{H}, \mathrm{m}, \mathrm{H}-5), 3.25-3.12(1 \mathrm{H}, \mathrm{m}, \mathrm{H}-3 \mathrm{a}), 2.00-2.10(1 \mathrm{H}, \mathrm{m}$, $\mathrm{H}-4), 2.20-2.30(1 \mathrm{H}, \mathrm{m}, \mathrm{H}-4)$.

\subsection{5. $\left(2 a S^{*} R^{*}, 3 a R^{*} S^{*}\right)$ Hexahydrofuro[2,3-b]furan-3-one, $37^{22 c}$}

Alkene 35 (13.75 g, $109.1 \mathrm{mmol}$ ) was dissolved in dichloromethane $(70 \mathrm{~mL})$ and the solution cooled to $-78^{\circ} \mathrm{C}$. Ozone was passed through the solution for $2 \mathrm{~h}$ after which time the solution turned blue. The system was purged with oxygen for $20 \mathrm{~min}$. Dimethylsulfide $(16 \mathrm{~mL}, 218.2 \mathrm{mmol})$ was added and the solution stirred overnight at room temperature. The resulting solution was washed with brine $(100 \mathrm{~mL})$, dried $\mathrm{MgSO}_{4}$ and concentrated in vacuo. The residue was purified by column chromatography (flash silica $20 \% \mathrm{EtOAc/petrol)} \mathrm{to} \mathrm{afford} \mathrm{the} \mathrm{title}$ compound, a white crystalline solid $(3.50 \mathrm{~g}, 74 \%, \mathrm{mp} 41.5-$ $43.0^{\circ} \mathrm{C}$; no lit. mp). $\nu_{\max }(\mathrm{film}) / \mathrm{cm}^{-1} 2957$ (s), 2873 (m), 1760 (s), 1440 (m), 1246 (m); ${ }^{1} \mathrm{H}$ NMR (300 MHz, $\left.\mathrm{CDCl}_{3}\right)$ $\delta 6.05(1 \mathrm{H}, \mathrm{d}, J=5.0 \mathrm{~Hz}, \mathrm{H}-6 \mathrm{a}), 4.19(2 \mathrm{H}, \mathrm{s}, \mathrm{H}-2), 4.15-4.05$ $(1 \mathrm{H}, \mathrm{m}, \mathrm{H}-5), 3.80(1 \mathrm{H}, \mathrm{q}, J=8.0 \mathrm{~Hz}, \mathrm{H}-5), 3.10-3.00(1 \mathrm{H}$, m, H-3a), 2.32-2.22 (2H, m, H-4); ${ }^{13} \mathrm{C}$ NMR $(75 \mathrm{MHz}$, $\left.\mathrm{CDCl}_{3}\right) \delta 215.3,107.7,71.4,67.4,49.4,30.1 ; \mathrm{m} / \mathrm{z}$ (CI) 129 $\left(\mathrm{MH}^{+}, 18 \%\right) 128\left(\mathrm{M}^{+}, 37 \%\right) ; 146\left(\mathrm{MNH}_{4}^{+}, 10 \%\right)$, found $\mathrm{M}^{+}$ 128.0471, $\mathrm{C}_{6} \mathrm{H}_{8} \mathrm{O}_{3}$ requires $\mathrm{M}^{+} 128.0473$.

\subsection{6. (E/Z)-(2aS*R*,3aR* $\left.S^{*}\right)$ Hexahydrofuro[2,3-b]furan- 3-one toluenesulfonylhydrazone, $\mathbf{3 8 a}$}

Ketone 37 (6.46 g, $50 \mathrm{mmol})$ and $p$-toluenesulfonyl hydrazide $(10.23 \mathrm{~g}, 55 \mathrm{mmol})$ were dissolved in THF $(50 \mathrm{~mL})$ and the solution stirred for $3 \mathrm{~h}$. The solvent was removed in vacuo. Purification was carried out by recrystallization $(\mathrm{MeOH} / \mathrm{hexane})$ to afford the title compound, a yellow solid $(E: Z=1: 1)(11.79 \mathrm{~g}$, $79 \%$, mp $141-145.5^{\circ} \mathrm{C}$ ). $\nu_{\max }($ film $) / \mathrm{cm}^{-1} 3206(\mathrm{br}), 2959(\mathrm{~s})$, 2873 (s), 1597 (s), 1342 (s), 1165 (s), 1015 (s); ${ }^{1} \mathrm{H}$ NMR $\left(300 \mathrm{MHz}, \mathrm{CDCl}_{3}\right) \delta 8.45(1 \mathrm{H}, \mathrm{s}, \mathrm{NH}), 8.05(1 \mathrm{H}, \mathrm{s}, \mathrm{NH}), 7.87$ $(2 \mathrm{H}, \mathrm{s}, \operatorname{Ar} H), 7.84(2 \mathrm{H}, \mathrm{s}, \operatorname{Ar} H), 7.37(2 \mathrm{H}, \mathrm{d}, J=3.2 \mathrm{~Hz}$, $\operatorname{Ar} H), 7.34(2 \mathrm{H}, \mathrm{d}, J=3.2 \mathrm{~Hz}, \operatorname{Ar} H), 5.87(1 \mathrm{H}, \mathrm{d}, J=5 \mathrm{~Hz}, \mathrm{H}-$ 6a), $5.83(1 \mathrm{H}, \mathrm{d}, J=5 \mathrm{~Hz}, \mathrm{H}-6 \mathrm{a}), 4.50-4.30(4 \mathrm{H}, \mathrm{m}, \mathrm{H}-2)$, 4.04-3.97 (1H, m, H-5), 3.97-3.90 (1H, m, H-5), 3.83-3.73 $(1 \mathrm{H}, \mathrm{m}, \mathrm{H}-5), 3.67-3.58(1 \mathrm{H}, \mathrm{m}, \mathrm{H}-5), 3.38-3.30(2 \mathrm{H}, \mathrm{m}, \mathrm{H}-$ 3a), 2.46 (6H, s, $\left.\mathrm{ArCH}_{3}\right), 2.28-2.10(2 \mathrm{H}, \mathrm{m}, \mathrm{H}-4), 2.08-1.98$ $(2 \mathrm{H}$, br dd, $J=12.5,5.9 \mathrm{~Hz}, \mathrm{H}-4) ;{ }^{13} \mathrm{C}$ NMR $\left(75 \mathrm{MHz}, \mathrm{CDCl}_{3}\right)$ $\delta 165.0,162.0,145.0,144.8,135.1,135.0,130.2,130.0,128.2$, 128.1, 109.7, 108.8, 70.5, 68.4, 67.8, 67.3, 47.1, 42.9, 33.2, 29.3, 21.9; $\mathrm{m} / \mathrm{z}$ (CI) $297\left(\mathrm{MH}^{+}, 80 \%\right)$ found $\mathrm{C} 53.19 \%, \mathrm{H}$ $5.61 \%, \mathrm{~N} 9.35 \%, \mathrm{MH}^{+} 297.0912, \mathrm{C}_{13} \mathrm{H}_{16} \mathrm{~N}_{2} \mathrm{O}_{4} \mathrm{~S}$ requires $\mathrm{C}$ $52.69 \%, \mathrm{H} 5.44 \%, \mathrm{~N} 9.45 \%, \mathrm{MH}^{+} 297.09089$.

\subsection{7. (E/Z)-(2aS* $\left.R^{*}, 3 a R^{*} S^{*}\right)$ Hexahydrofuro[2,3-b]furan- \\ 3-one 2,4,6-(tri-isopropyl)phenylsulfonylhyrazone, $\mathbf{3 8 b}$}

To a solution of the ketone $37(1.81 \mathrm{~g}, 14.1 \mathrm{mmol})$ in THF $(15 \mathrm{~mL})$ was added 2,4,6-tri-isopropylbenzenesulfonylhydrazide $(4.20 \mathrm{~g}, 14.1 \mathrm{mmol})$ and the solution stirred for $3 \mathrm{~h}$. The solvent was then removed in vacuo and the residue purified by column chromatography (flash silica 30\% EtOAc/petrol with $\left.5 \% \mathrm{Et}_{3} \mathrm{~N}\right)$ to afford the title compound as a white solid $(E: Z=1: 1)\left(2.40 \mathrm{~g}, 42 \%, \mathrm{mp} 101.0-103.0{ }^{\circ} \mathrm{C}\right) . \nu_{\max }$ (film)/ $\mathrm{cm}^{-1} 3196$ (br), 2960 (s), 2931 (m), 2870 (m), 1599 (s), 1462 (m); ${ }^{1} \mathrm{H}$ NMR $\left(300 \mathrm{MHz}, \mathrm{CDCl}_{3}\right) \delta 8.49(1 \mathrm{H}, \mathrm{s}, \mathrm{NH}), 8.32$ $(1 \mathrm{H}, \mathrm{s}, \mathrm{N} H), 7.22(1 \mathrm{H}, \mathrm{s}, \operatorname{Ar} H), 7.21(1 \mathrm{H}, \mathrm{s}, \operatorname{Ar} H), 5.85(1 \mathrm{H}$, d, $J=4.9 \mathrm{~Hz}, \mathrm{H}-6 \mathrm{a}), 5.82(1 \mathrm{H}, \mathrm{d}, J=4.9 \mathrm{~Hz}, \mathrm{H}-6 \mathrm{a}), 4.50-4.35$ $(4 \mathrm{H}, \mathrm{m}, \mathrm{H}-2), 4.26$ (4H, sep, $\left.J=7.0 \mathrm{~Hz}, \mathrm{ArCH} \mathrm{H}-2^{\prime}, 6^{\prime}\right), 4.18-$ $4.08(1 \mathrm{H}, \mathrm{q}, J=7.0 \mathrm{~Hz}, \mathrm{H}-5), 4.18-4.08(1 \mathrm{H}, \mathrm{q}, J=7.0 \mathrm{~Hz}, \mathrm{H}-$ 5), 4.08-3.60 (4H, m, H-2,5), 3.42-3.36 (1H, m, H-3a), 3.35-3.28 (1H, m, H-3a), $2.92(2 \mathrm{H}$, sep, $J=6.9 \mathrm{~Hz}, \mathrm{ArCH} \mathrm{H}-$ $\left.4^{\prime}\right), 2.10-2.00(4 \mathrm{H}, \mathrm{m}, \mathrm{H}-4), 1.35-1.25\left(36 \mathrm{H}, \mathrm{m}, 6 \times \mathrm{CH}_{3}\right)$; ${ }^{13} \mathrm{C}$ NMR $\left(75 \mathrm{MHz}, \mathrm{CDCl}_{3}\right) \delta 171.3,161.7,159.6,153.7$, 153.6, 151.6, 151.5, 130.7, 130.6, 123.9, 123.8, 109.5, 108.6, 70.2, 68.2, 67.6, 67.1, 60.4, 46.8, 42.3, 34.2, 32.7, 29.9, 29.8, 29.1, 24.8, 24.7, 23.5, 21.0, 14.2; m/z (CI) $409\left(\mathrm{MH}^{+}, 3 \%\right)$ $189\left(\mathrm{M}^{+}, 45 \%\right) ; 426\left(\mathrm{MNH}_{4}^{+}, 22 \%\right)$, found $\mathrm{MH}^{+}$409.2171, $\mathrm{C}_{21} \mathrm{H}_{32} \mathrm{~N}_{2} \mathrm{SO}_{4}$ requires $\mathrm{MH}^{+} 409.2161$. 


\subsection{8. (2aS* $\left.R^{*}, 3 a R^{*} S^{*}\right)-3 a, 4,5,6 a-$ Tetrahydrofuro[2,3- \\ b]furan, 31 (Method $A)^{22}$}

Sodium $(1.49 \mathrm{~g}, 67 \mathrm{mmol})$ was added to trigol $(50 \mathrm{~mL})$ and the suspension stirred until the metal had dissolved $(2 \mathrm{~h}$ ). Hydrazone 38a (10.0 g, $34 \mathrm{mmol})$ was added and the solution heated to $120^{\circ} \mathrm{C}$ for $2 \mathrm{~h}$. Short path distillation under reduced pressure afforded the title compound, a colourless oil (2.70 g, 73\%). $\nu_{\max }(\mathrm{film}) / \mathrm{cm}^{-1} 2958$ (s), 2870 (s), 1597 (s), 1462 (s), $1128(\mathrm{~m}), 950(\mathrm{~s}) ;{ }^{1} \mathrm{H}$ NMR $\left(300 \mathrm{MHz}, \mathrm{CDCl}_{3}\right) \delta 6.44(1 \mathrm{H}$, app. t, $J=2.5 \mathrm{~Hz}, \mathrm{H}-2), 6.07(1 \mathrm{H}, \mathrm{d}, J=6 \mathrm{~Hz}, \mathrm{H}-6 \mathrm{a}), 4.77$ $(1 \mathrm{H}, \mathrm{t}, J=2.5 \mathrm{~Hz}, \mathrm{H}-3), 4.00(1 \mathrm{H}$, app. $\mathrm{t}, J=7.7 \mathrm{~Hz}, \mathrm{H}-5)$, $3.78-3.70(1 \mathrm{H}, \mathrm{m}, \mathrm{H}-5), \quad 3.55-3.45 \quad(1 \mathrm{H}, \mathrm{m}, \mathrm{H}-3 \mathrm{a})$, $2.12-1.88(1 \mathrm{H}, \mathrm{m}, \mathrm{H}-4), 1.8(1 \mathrm{H}, \mathrm{dd}, J=12.4,5.1 \mathrm{~Hz}, \mathrm{H}-4)$; ${ }^{13} \mathrm{C}$ NMR $\left(75 \mathrm{MHz}, \mathrm{CDCl}_{3}\right) \delta 146.5,109.7,102.0,67.0$, 46.5, 32.1; m/z (CI) $112\left(\mathrm{M}^{+}, 23 \%\right) 113\left(\mathrm{MH}^{+}, 60 \%\right), 130$ $\left(\mathrm{MNH}_{4}^{+}, 100 \%\right)$; found $\mathrm{MNH}_{4}^{+} 130.0865, \mathrm{C}_{6} \mathrm{H}_{8} \mathrm{O}_{2}$ requires $\mathrm{MNH}_{4}^{+} 130.09066$.

\subsection{9. $\left(2 a S^{*} R^{*}, 3 a R^{*} S^{*}\right)-3 a, 4,5,6 a-$ Tetrahydrofuro[2,3- b]furan, 31 (Method B)}

Sodium (408 mg, $17.8 \mathrm{mmol}$ ) was added to ethylene glycol $(30 \mathrm{~mL})$ and the suspension stirred until the metal had dissolved $(2 \mathrm{~h}$ ). To this solution was added $\mathbf{3 8 b}$ ( $3.63 \mathrm{~g}$, $8.9 \mathrm{mmol}$ ) and the reaction mixture heated to $100{ }^{\circ} \mathrm{C}$ for $2 \mathrm{~h}$. The cooled mixture was poured into water $(50 \mathrm{~mL})$ and extracted with ether $(3 \times 50 \mathrm{~mL})$. The combined organic phases were dried $\left(\mathrm{MgSO}_{4}\right)$ and concentrated in vacuo to afford the title compound $(768 \mathrm{mg}, 77 \%$ ) as a colourless oil.

\subsubsection{0. (3aS* $\left.R^{*}, 6 a S^{*} R^{*}\right)$-4-Chloro-2,3,3a,6a- tetrahydrofuro[2,3-b]furan, 32}

Sodium (303 mg, $13.2 \mathrm{mmol}$ ) was added to ethylene glycol $(20 \mathrm{~mL})$ and allowed to stir until all of the sodium had reacted (approximately $2 \mathrm{~h}$ ). To this solution was added $\mathbf{3 8 b}(2.70 \mathrm{~g}$, $6.6 \mathrm{mmol}$ ) and the mixture heated at $100{ }^{\circ} \mathrm{C}$ for $2 \mathrm{~h}$. The cooled mixture was poured into water $(30 \mathrm{~mL})$ and extracted with dichloromethane $(3 \times 15 \mathrm{~mL})$, which was then dried $\left(\mathrm{MgSO}_{4}\right)$. Sulfurylchloride ( $530 \mu \mathrm{L}, 6.6 \mathrm{mmol}$ ) was added to the dried organic phase, which was stirred for $30 \mathrm{~min}$. Air was blown through the solution for $30 \mathrm{~min}$, and the solvent was removed in vacuo. THF $(50 \mathrm{~mL})$ was added, followed by potassium tert-butoxide (738 mg, $6.6 \mathrm{mmol}$ ), and the solution was stirred for $5 \mathrm{~h}$. The solvent was removed in vacuo, water $(30 \mathrm{~mL})$ added and the mixture extracted with dichloromethane $(3 \times 50 \mathrm{~mL})$. The extracts were dried $\left(\mathrm{MgSO}_{4}\right)$ and concentrated in vacuo. The residue was purified by column chromatography (flash silica, 5\% EtOAc/petrol) to afford the title compound (273 mg, 28\%) as a colourless oil. $\nu_{\max }\left(\mathrm{cm}^{-1}\right) 2978(\mathrm{~s}), 2884$ (s), $1636(\mathrm{~m}), 1123$ (s), 1057 (s); ${ }^{1} \mathrm{H}$ NMR (300 MHz, $\left.\mathrm{CDCl}_{3}\right)$ $\delta 6.48(1 \mathrm{H}, \mathrm{d}, J=2 \mathrm{~Hz}, \mathrm{H}-5), 6.10(1 \mathrm{H}, \mathrm{d}, J=6 \mathrm{~Hz}, \mathrm{H}-6 \mathrm{a})$, $4.11(1 \mathrm{H}, \mathrm{t}, J=8 \mathrm{~Hz}, \mathrm{H}-2), 3.70-3.85(1 \mathrm{H}, \mathrm{m}, \mathrm{H}-3 \mathrm{a}), 3.55$ $(1 \mathrm{H}, \mathrm{m}, \mathrm{H}-2), 1.90-2.20(2 \mathrm{H}, \mathrm{m}, \mathrm{H}-3) ;{ }^{13} \mathrm{C}$ NMR $(75 \mathrm{MHz}$, $\left.\mathrm{CDCl}_{3}\right) \delta 141.8,109.6,107.5,67.0,50.0,29.2 ; \mathrm{m} / \mathrm{z}(\mathrm{EI}), 147$ $\left(\mathrm{M}^{+}+\mathrm{H}, 32 \%\right), 146\left(\mathrm{M}^{+}, 69 \%\right) ;\left(\mathrm{CI}, \mathrm{NH}_{3}\right) \mathrm{m} / \mathrm{z} 164\left(\mathrm{MNH}_{4}^{+}\right.$, $100 \%), 147\left(\mathrm{M}^{+}+1,40 \%\right), 146\left(\mathrm{M}^{+}, 75 \%\right)$; found 146.0130 , $\mathrm{C}_{6} \mathrm{H}_{7} \mathrm{O}_{2}^{35} \mathrm{Cl}$ requires 146.0134 .
3.1.11. $\left(2 a S^{*} R^{*}, 3 a R^{*} S^{*}\right)$-Pentacarbonyl [ethoxy $(3 a, 4,5,6 a-$ tetrahydrofuro[2,3-b]furan-2-yl)carbene] chromium(0), 5

To a degassed solution of enol ether $\mathbf{3 1}(1.71 \mathrm{~g}, 15.3 \mathrm{mmol})$ in THF $(25 \mathrm{~mL})$ at $-78{ }^{\circ} \mathrm{C}$ was added tert-butyl lithium $(9 \mathrm{~mL}, 1.7 \mathrm{M}$ in pentane, $15.3 \mathrm{mmol})$ dropwise and the solution stirred for $15 \mathrm{~min}$ at $-78^{\circ} \mathrm{C}$ and then at $17^{\circ} \mathrm{C}$ for 30 min to give a yellow solution. The solution was recooled to $-78{ }^{\circ} \mathrm{C}$ and chromium hexacarbonyl $(3.37 \mathrm{~g}, 15.3 \mathrm{mmol})$ was added and the mixture warmed to $17^{\circ} \mathrm{C}$ and stirred for $2 \mathrm{~h}$ giving a deep red colour. The solvent was then removed in vacuo and degassed water $(20 \mathrm{~mL})$ added, followed by triethyloxonium tetrafluoroborate $(4.36 \mathrm{~g}, 23 \mathrm{mmol})$ and immediately the products extracted with pentane $(3 \times 40 \mathrm{~mL})$. The combined organic phases were dried $\left(\mathrm{MgSO}_{4}\right)$, and concentrated in vacuo. Purification by column chromatography under a nitrogen atmosphere (flash silica degassed 5\% EtOAc/petrol) afforded a red amorphous solid. Recrystallization from hexane afforded the title compound, a deep red-coloured solid $(2.88 \mathrm{~g}$, $\left.52 \%, \mathrm{mp} 57-63^{\circ} \mathrm{C}\right) . \nu_{\max }(\mathrm{film}) / \mathrm{cm}^{-1} 2961(\mathrm{~m}), 2876(\mathrm{~m})$, 2060 (m), 1993 (w), 1929 (s), 1725 (w), 1574 (w), 1214 $(\mathrm{m}), 1021(\mathrm{~m}) ;{ }^{1} \mathrm{H}$ NMR $\left(300 \mathrm{MHz}, \mathrm{CDCl}_{3}\right) \delta 6.25(1 \mathrm{H}, \mathrm{d}$, $J=5.6 \mathrm{~Hz}, \mathrm{H}-6 \mathrm{a}), 5.40(1 \mathrm{H}, \mathrm{d}, J=3.6 \mathrm{~Hz}, \mathrm{H}-3), 5.20-5.08$ $\left(2 \mathrm{H}, \mathrm{q}, J=7.0 \mathrm{~Hz}, \mathrm{OCH}_{2} \mathrm{CH}_{3}\right), 4.11(1 \mathrm{H}$, app. t $J=8.1 \mathrm{~Hz}$, $\mathrm{H}-5), 3.85-3.75(1 \mathrm{H}, \mathrm{m}, \mathrm{H}-5), 3.75-3.65(1 \mathrm{H}, \mathrm{m}, \mathrm{H}-3 \mathrm{a})$, $2.15-2.05(1 \mathrm{H}, \mathrm{m}, \mathrm{H}-4), 1.96-1.88(1 \mathrm{H}, \mathrm{dd}, J=11.7,4.3 \mathrm{~Hz}$, $\mathrm{H}-4), 1.68-1.60\left(3 \mathrm{H}, \mathrm{t}, J=7.0 \mathrm{~Hz}, \mathrm{OCH}_{2} \mathrm{CH}_{3}\right) ;{ }^{13} \mathrm{C} \mathrm{NMR}$ $\left(75 \mathrm{MHz}, \mathrm{CDCl}_{3}\right) \delta 324.2,224.7,216.4,164.1,109.4,103.0$, $76.3,66.9,60.4,47.4,31.2,15.1,14.2$; found $\mathrm{C} 46.58 \%, \mathrm{H}$ $3.48 \%, \mathrm{C}_{14} \mathrm{H}_{12} \mathrm{O}_{8} \mathrm{Cr}$ requires $\mathrm{C} 46.68 \%$, H $3.36 \%$.

\subsubsection{2. tert-Butyl(2-methoxy-1-ethynyl)dimethylsilane, 28}

To a solution of di-isopropylamine $(22.4 \mathrm{~mL}, 160 \mathrm{mmol})$ in THF $(300 \mathrm{~mL})$ at $-78^{\circ} \mathrm{C}$ was added dropwise $n$-BuLi $(100 \mathrm{~mL}, 1.6 \mathrm{M}$ in hexane, $160 \mathrm{mmol})$. The resulting solution was left to stir for $20 \mathrm{~min}$ at $-78^{\circ} \mathrm{C}$, then at $0{ }^{\circ} \mathrm{C}$ for $1 \mathrm{~h}$. Chloroacetalaldehyde dimethylacetal $(6.0 \mathrm{~mL}, 53.3 \mathrm{mmol})$ was then added dropwise at $-78{ }^{\circ} \mathrm{C}$ and brought to $17^{\circ} \mathrm{C}$ to stir for $4 \mathrm{~h}$. The reaction was recooled to $-78^{\circ} \mathrm{C}$ and TBDSCl $(8.0 \mathrm{~g}, 53.3 \mathrm{mmol})$ was added and the solution stirred overnight at $17{ }^{\circ} \mathrm{C}$. The mixture was concentrated in vacuo and the residue partitioned between diethyl ether $(3 \times 100 \mathrm{~mL})$ and water $(200 \mathrm{~mL})$. The combined organic phases were dried $\left(\mathrm{MgSO}_{4}\right)$ and concentrated in vacuo. The residue was purified by Kügelrohr distillation $\left(760 \mathrm{mmHg}, 110^{\circ} \mathrm{C}\right)$ to yield the title compound, a yellow oil $(6.10 \mathrm{~g}, 22 \%) \cdot \nu_{\max }(\mathrm{film}) / \mathrm{cm}^{-1} 2953$ (s), 2932 (s), 2892 (s), 2858 (s), 2187 (s), 1465 (s); ${ }^{1} \mathrm{H}$ NMR $\left(300 \mathrm{MHz}, \mathrm{CDCl}_{3}\right) \delta 3.91(3 \mathrm{H}, \mathrm{s}, \mathrm{OMe}), 0.91(9 \mathrm{H}, \mathrm{s},-$ $\left.\mathrm{C}\left(\mathrm{CH}_{3}\right)_{3}\right), 0.80\left(6 \mathrm{H}, \mathrm{s}, \mathrm{Si}\left(\mathrm{CH}_{3}\right)_{2}\right) ;{ }^{13} \mathrm{C}$ NMR $(75 \mathrm{MHz}$, $\left.\mathrm{CDCl}_{3}\right) \delta 111.5,66.1,26.3,25.9,16.9,-3.7 ; \mathrm{m} / \mathrm{z}$ (CI) 188 $\left(\mathrm{MNH}_{4}^{+}, 100 \%\right), 171\left(\mathrm{MH}^{+}, 20 \%\right)$, found $\mathrm{M}^{+}$170.1129, $\mathrm{C}_{9} \mathrm{H}_{18} \mathrm{OSi}$ requires 170.11269 .

\subsubsection{3. tert-Butyl-(1-chloro-2-methoxyethenyl)- dimethylsilane, 39}

To a solution of di-isopropylamine $(35.0 \mathrm{~mL}, 250 \mathrm{mmol})$ in THF $(400 \mathrm{~mL})$ at $-78{ }^{\circ} \mathrm{C}$ was added dropwise $n$-BuLi $(100 \mathrm{~mL}, 2.5 \mathrm{M}$ in hexane, $250 \mathrm{mmol})$. The resulting solution 
was left to stir for $20 \mathrm{~min}$ at $-78{ }^{\circ} \mathrm{C}$, then at $0{ }^{\circ} \mathrm{C}$ for $1 \mathrm{~h}$. Chloroacetalaldehyde dimethylacetal $(9.4 \mathrm{~mL}, 83.3 \mathrm{mmol})$ was then added dropwise at $-78{ }^{\circ} \mathrm{C}$ and brought to $17{ }^{\circ} \mathrm{C}$ and left to stir for $4 \mathrm{~h}$. The reaction was recooled to $-78^{\circ} \mathrm{C}$ and $\mathrm{TBDSCl}$ $(12.50 \mathrm{~g}, 83.3 \mathrm{mmol})$ was added and the solution stirred overnight at $17{ }^{\circ} \mathrm{C}$. The mixture was concentrated in vacuo and the residue partitioned between diethyl ether $(3 \times 100 \mathrm{~mL})$ and water $(200 \mathrm{~mL})$. The combined organic phases were dried $\left(\mathrm{MgSO}_{4}\right)$ and concentrated in vacuo. The residue was purified by Kügelrohr distillation $\left(760 \mathrm{mmHg}, 110^{\circ} \mathrm{C}\right)$ to afford the $t i$ tle compound, a yellow oil $(6.0 \mathrm{~g}, 35 \%) \cdot \nu_{\max }(\mathrm{film}) / \mathrm{cm}^{-1} 2955$ (s), 2932 (s), 2891 (s), 2858 (s), 1723 (s), 1623 (s); ${ }^{1} \mathrm{H}$ NMR $\left(300 \mathrm{MHz}, \mathrm{CDCl}_{3}\right) \delta 6.30(1 \mathrm{H}, \mathrm{s}, \mathrm{CH}), 3.80(3 \mathrm{H}, \mathrm{s}, \mathrm{OMe})$, $0.98\left(9 \mathrm{H}, \mathrm{s},-\mathrm{C}\left(\mathrm{CH}_{3}\right)_{3}\right), 0.18\left(6 \mathrm{H}, \mathrm{s}, \mathrm{Si}\left(\mathrm{CH}_{3}\right)_{2}\right) ;{ }^{13} \mathrm{C} \mathrm{NMR}$ $\left(75 \mathrm{MHz}, \mathrm{CDCl}_{3}\right) \delta 152.5,107.1,60.8,26.9,17.0,-6.1$.

\subsubsection{4. $\left(3 a S^{*} R^{*}, 8 a R^{*} S^{*}\right)-5$-(tert-Butyl-dimethylsilanyl)-7- ethoxy-6-methoxy-2,3,3a,8a-tetrahydro-1.8-dioxa- \\ cyclopenta[a]inden-4-ol, 40}

The carbene complex $5(1.78 \mathrm{~g}, 4.9 \mathrm{mmol})$ and acetylene $28(2.10 \mathrm{~g}, 12.3 \mathrm{mmol})$ were dissolved in THF $(30 \mathrm{~mL})$, degassed and brought to reflux for $2 \mathrm{~h}$ under an atmosphere of nitrogen. On cooling to ambient temperature the reaction mixture was filtered through a pad of Celite and concentrated in vacuo. The residue was purified by column chromatography (flash silica $15 \% \mathrm{EtOAc/petrol)} \mathrm{affording} \mathrm{the} \mathrm{title} \mathrm{compound}$ as a brown oil (550 mg, 31\%). Recrystallization of a sample from hexane at $-78{ }^{\circ} \mathrm{C}$ afforded the title compound, a cream-coloured solid ( $\left.\mathrm{mp} 110-111^{\circ} \mathrm{C}\right) \cdot \nu_{\max }($ film $) / \mathrm{cm}^{-1}$ 3416, 2948, 2886, 2855, 1596; ${ }^{1} \mathrm{H}$ NMR (300 MHz, $\left.\mathrm{CDCl}_{3}\right)$ $\delta 6.38(1 \mathrm{H}, \mathrm{d}, J=5.9 \mathrm{~Hz}, \mathrm{H}-8 \mathrm{a}), 5.02(1 \mathrm{H}, \mathrm{s}, \mathrm{OH}), 4.18-$ $4.08\left(3 \mathrm{H}, \mathrm{m}, \mathrm{H}-2, \mathrm{OCH}_{2} \mathrm{CH}_{3}\right), 4.05-3.96(1 \mathrm{H}, \mathrm{m}, \mathrm{H}-3 \mathrm{a})$, $3.87\left(3 \mathrm{H}, \mathrm{s}, \mathrm{OCH}_{3}\right), 3.80-3.70(1 \mathrm{H}, \mathrm{m}, \mathrm{H}-2), 2.23-2.15$ $(2 \mathrm{H}, \mathrm{m}, \mathrm{H}-3), 1.35\left(3 \mathrm{H}, \mathrm{t}, J=7.0 \mathrm{~Hz}, \mathrm{OCH}_{2} \mathrm{CH}_{3}\right), 0.92(9 \mathrm{H}$, s, $\left.\mathrm{Si}-\left(\mathrm{CH}_{3}\right)_{3}\right), 0.42\left(3 \mathrm{H}, \mathrm{s}, \mathrm{Si}-\mathrm{CH}_{3}\right), 0.40\left(3 \mathrm{H}, \mathrm{s}, \mathrm{Si}-\mathrm{CH}_{3}\right)$; ${ }^{13} \mathrm{C}$ NMR $\left(75 \mathrm{MHz}, \mathrm{CDCl}_{3}\right) \delta 159.2,154.9,152.4,129.5$, 112.8, 109.8, 106.2, 68.7, 67.8, 60.9, 45.0, 31.6, 27.1, 27.0, 18.6, 15.7, -1.5, -1.6; m/z (CI) $367\left(\mathrm{MH}^{+}, 100 \%\right)$; found C $61.71 \%, \mathrm{H} 8.15 \%, \mathrm{M}^{+} 366.1866, \mathrm{C}_{19} \mathrm{H}_{30} \mathrm{O}_{5} \mathrm{Si}$ requires $\mathrm{C}$ $62.26 \%, \mathrm{H} 8.25 \% \mathrm{M}^{+} 366.18624$.

A second component $\left(3 \mathrm{a} S^{*} R^{*}, 7 \mathrm{a} R^{*} S^{*}, 3 \mathrm{~b} R^{*} S^{*}, 6 \mathrm{a} S^{*} R^{*}\right)-5-$ (tert-butyldimethylsilanyl)-6-ethoxy-2,3,3a,3b,6a,7a-hexahydocyclopenta[$[b]$ furo $[3,2-d]$ furan-4-one, 42, was also isolated from the above reaction as a white solid, which was recrystallized from hexane $\left(21 \mathrm{mg}, 1 \%, \mathrm{mp} 99-101^{\circ} \mathrm{C}\right) . \nu_{\max }$ (film)/ $\mathrm{cm}^{-1} 2952$ (s), 2931 (s), 2888 (s), 2856 (s), 1685 (s), 1571 (s); ${ }^{1} \mathrm{H} \mathrm{NMR}\left(300 \mathrm{MHz}, \mathrm{CDCl}_{3}\right) \delta 5.74(1 \mathrm{H}, \mathrm{d}, J=4.7 \mathrm{~Hz}$, H-7a), $5.35(1 \mathrm{H}, \mathrm{d}, J=6.3 \mathrm{~Hz}, \mathrm{H}-6 \mathrm{a}), 4.64-4.52(1 \mathrm{H}, \mathrm{dq}$, $\left.J=9.8,7.2 \mathrm{~Hz},-\mathrm{OCH}_{2} \mathrm{CH}_{3}\right), 4.44-4.32(1 \mathrm{H}, \mathrm{dq}, J=9.8$, $\left.7.2 \mathrm{~Hz},-\mathrm{OCH}_{2} \mathrm{CH}_{3}\right), 4.08-3.94(2 \mathrm{H}, \mathrm{m}, \mathrm{H}-2), 3.10-3.02$ $(1 \mathrm{H}, \mathrm{m}, \mathrm{H}-3 \mathrm{a}), 2.98-2.92(1 \mathrm{H}, \mathrm{dd}, J=6.3,2.9 \mathrm{~Hz}, \mathrm{H}-3 \mathrm{~b})$, 2.28-2.14 (1H, m, H-3), 2.00-1.90 (1H, m, H-3), 1.44$1.38\left(3 \mathrm{H}, \mathrm{t}, J=7.2 \mathrm{~Hz},-\mathrm{OCH}_{2} \mathrm{CH}_{3}\right), 0.90\left(9 \mathrm{H}, \mathrm{s}, \mathrm{Si}^{t} B u \mathrm{Me}_{2}\right)$, $0.22\left(3 \mathrm{H}, \mathrm{s}, \mathrm{Si}^{t} \mathrm{BuMe} e_{2}\right), 0.21\left(3 \mathrm{H}, \mathrm{s}, \mathrm{Si}^{t} \mathrm{Bu} M e_{2}\right) ;{ }^{13} \mathrm{C} \mathrm{NMR}$ $\left(75 \mathrm{MHz}, \mathrm{CDCl}_{3}\right) \delta 206.9,192.4,114.6,111.2,79.7,67.9$, $66.9,57.3,46.1,33.3,26.8,17.9,15.4,-5.3,-5.5 ; \mathrm{m} / \mathrm{z}(\mathrm{CI})$ $325\left(\mathrm{MH}^{+}, 28 \%\right)$, found $\mathrm{C} 62.84 \%, \mathrm{H} 8.64 \%, \mathrm{MH}^{+}$
325.1835, $\mathrm{C}_{17} \mathrm{H}_{28} \mathrm{O}_{4} \mathrm{Si}_{2}$ requires $\mathrm{C} 62.92 \%, \mathrm{H} 8.70 \%, \mathrm{MH}^{+}$ 325.1828 .

Also isolated was a trace amount of $\left(4 R^{*} S^{*}, 5 S^{*} R^{*}\right)-2,5$ bis-(tert-butyldimethylsilanyl)-3,4-dimethoxycyclopent-2enone, 43 (mp $\left.72-73{ }^{\circ} \mathrm{C}\right)$. $\nu_{\max }\left(\right.$ film) $/ \mathrm{cm}^{-1} 2951(\mathrm{~s}), 2890(\mathrm{~s})$, 2855 (s), 1669 (s), 1582 (s), 1465 (s); ${ }^{1} \mathrm{H}$ NMR (300 MHz, $\left.\mathrm{CDCl}_{3}\right) \delta 4.78(1 \mathrm{H}, \mathrm{d}, J=6.7 \mathrm{~Hz}, \mathrm{H}-4), 3.89(3 \mathrm{H}, \mathrm{s}, \mathrm{C}=\mathrm{C}-$ OMe), 3.42 (3H, s, CH-OMe), $2.74(1 \mathrm{H}, \mathrm{d}, J=6.7 \mathrm{~Hz}, \mathrm{H}-5)$, $0.98\left(9 \mathrm{H}, \mathrm{s}, \mathrm{C}=\mathrm{CSi}-\mathrm{C}\left(\mathrm{CH}_{3}\right)_{3}\right), 0.86\left(9 \mathrm{H}, \mathrm{s}, \mathrm{Si}-\mathrm{C}\left(\mathrm{CH}_{3}\right)_{3}\right)$, $0.18\left(3 \mathrm{H}, \mathrm{s}, \mathrm{SiCH}_{3}\right), 0.17\left(3 \mathrm{H}, \mathrm{s}, \mathrm{SiCH}_{3}\right), 0.16(3 \mathrm{H}, \mathrm{s}$, $\left.\mathrm{SiCH}_{3}\right), 0.10\left(3 \mathrm{H}, \mathrm{s}, \mathrm{SiCH}_{3}\right) ;{ }^{13} \mathrm{C} \mathrm{NMR}\left(75 \mathrm{MHz}, \mathrm{CDCl}_{3}\right)$ $\delta$ 205.2, 190.5, 118.6, 81.2, 76.9, 58.5, 57.9, 47.6, 44.3, $30.0,27.7,27.0,26.9,18.2,17.8,-4.0,-4.2,-4.9,-5.2$; $m / z$ (CI) $371 \quad\left(\mathrm{MH}^{+}, 100 \%\right)$ found $\mathrm{MH}^{+}$371.2447, $\mathrm{C}_{19} \mathrm{H}_{38} \mathrm{O}_{3} \mathrm{Si}$ requires $\mathrm{MH}^{+} 371.24388$.

\subsubsection{5. (3aS*R*,8aR* $\left.S^{*}\right)$-tert-Butyl-(7-ethoxy-6-methoxy- 2,3,3a,8a-terahydro-1,8-dioxa-cyclopenta[a]inden-4- yloxy)dimethylsilane, 49}

A solution of the carbene complex $5(500 \mathrm{mg}, 1.4 \mathrm{mmol})$ and acetylene 28 (950 $\mathrm{mg}, 5.6 \mathrm{mmol}$ ) in degassed toluene $(20 \mathrm{~mL})$ was brought to reflux for $4 \mathrm{~h}$, passed through a pad of Celite and concentrated in vacuo. The residue was purified by column chromatography (flash silica $15 \%$ EtOAc/petrol) to afford the cyclopenteneone $\mathbf{4 2}(80 \mathrm{mg}, 18 \%)$ and the title compound, a colourless oil (100 mg, 28\%). $\nu_{\max }\left(\right.$ film) $/ \mathrm{cm}^{-1} 2954$ (s), 2934 (s), 2888 (s), 2859 (s), 1723 (w), 1617 (s), 1503 (s); ${ }^{1} \mathrm{H}$ NMR $\left(300 \mathrm{MHz}, \mathrm{CDCl}_{3}\right) \delta 6.36(1 \mathrm{H}, \mathrm{d}, J=5.6 \mathrm{~Hz}, \mathrm{H}-8 \mathrm{a})$, $5.97(1 \mathrm{H}, \mathrm{s}, \mathrm{H}-5), 4.16-4.08\left(3 \mathrm{H}, \mathrm{m}, \mathrm{H}-2, \mathrm{OCH}_{2} \mathrm{CH}_{3}\right)$, 3.95-3.92 (1H, m, H-3a), 3.82 (3H, s, OMe), 3.73-3.64 (1H, m, H-2), 2.28-2.09 (2H, m, H-3), $1.38(3 \mathrm{H}, \mathrm{t}, J=7 \mathrm{~Hz}$, $\left.\mathrm{OCH}_{2} \mathrm{CH}_{3}\right), 1.02\left(9 \mathrm{H}, \mathrm{s},-\mathrm{C}\left(\mathrm{CH}_{3}\right)_{3}\right), 0.30\left(3 \mathrm{H}, \mathrm{s}, \mathrm{SiCH}_{3}\right)$, $0.25\left(3 \mathrm{H}, \mathrm{s}, \mathrm{SiCH}_{3}\right) ;{ }^{13} \mathrm{C} \mathrm{NMR}\left(75 \mathrm{MHz}, \mathrm{CDCl}_{3}\right) \delta 153.8$, 153.0, 147.3, 126.6, 112.3, 111.2, 97.2, 68.9, 67.6, 56.6, $45.8,45.4,31.9,26.5,25.9,18.3,15.7,-3.7,-4.0 ; \mathrm{m} / \mathrm{z}(\mathrm{CI})$ $366\left(\mathrm{M}^{+}, 20 \%\right), 367\left(\mathrm{MH}^{+}, 100 \%\right), 384\left(\mathrm{MNH}_{4}^{+}, 80 \%\right)$, found $\mathrm{M}^{+} 366.1866, \mathrm{C}_{19} \mathrm{H}_{30} \mathrm{O}_{5} \mathrm{Si}$ requires $\mathrm{M}^{+} 366.18624$.

\subsubsection{6. (3aS* $\left.R^{*}, 8 a R^{*} S^{*}\right)-7-$ Ethoxy-6-methoxy-2,3,3a,8a-} tetrahydro-1,8-dioxa-cyclopenta[a]inden-4-ol, 44

To a solution of phenol $(737 \mathrm{mg}, 2.0 \mathrm{mmol})$ in THF $(30 \mathrm{~mL})$ at $0{ }^{\circ} \mathrm{C}$ was added TBAF $(2.0 \mathrm{~mL}, 1 \mathrm{M}$ in THF, $2.0 \mathrm{mmol}$ ), and the mixture stirred at $17^{\circ} \mathrm{C}$ for $1 \mathrm{~h}$. The solution was diluted with diethyl ether $(30 \mathrm{~mL})$, washed with brine $(50 \mathrm{~mL})$, dried $\left(\mathrm{MgSO}_{4}\right)$ and concentrated in vacuo to afford a yellow solid. Recrystallization from EtOAc and hexane afforded the title compound as colourless crystals (257 mg, $\left.52 \%, \mathrm{mp} 119-120^{\circ} \mathrm{C}\right) . \nu_{\max }($ film $) / \mathrm{cm}^{-1} 3366,2979,1636$; ${ }^{1} \mathrm{H}$ NMR $\left(300 \mathrm{MHz}, \mathrm{CDCl}_{3}\right) \delta 6.38-6.36(1 \mathrm{H}, \mathrm{d}, J=5.6 \mathrm{~Hz}$, H-8a), 6.34 (1H, br s, OH), 6.20 (1H, s, H-5), 4.14-4.01 $\left(4 \mathrm{H}, \mathrm{m}, \mathrm{H}-2, \mathrm{OCH}_{2} \mathrm{CH}_{3}, \mathrm{H}-3 \mathrm{a}\right), 3.74$ (3H, s, OMe), 3.72$3.64(1 \mathrm{H}, \mathrm{m}, \mathrm{H}-2), 2.28-2.08(2 \mathrm{H}, \mathrm{m}, \mathrm{H}-3), 1.35(3 \mathrm{H}, \mathrm{t}$, $\left.J=7.0 \mathrm{~Hz}, \mathrm{OCH}_{2} \mathrm{CH}_{3}\right) ;{ }^{13} \mathrm{C} \mathrm{NMR}\left(75 \mathrm{MHz}, \mathrm{CDCl}_{3}\right) \delta 154.0$, 153.1, 148.3, 125.1, 112.6, 106.8, 93.9, 69.3, 67.8, 56.4, 44.8, 31.7, 15.6; $\mathrm{m} / \mathrm{z}$ (CI) $253\left(\mathrm{MH}^{+}, 100 \%\right)$ found $\mathrm{C}$ $61.45 \%, \mathrm{H} 6.42 \%, \mathrm{M}^{+} 252.0995, \mathrm{C}_{13} \mathrm{H}_{16} \mathrm{O}_{5}$ requires $\mathrm{C}$ $61.90 \%, \mathrm{H} 6.39 \%, \mathrm{M}^{+} 252.09976$. 
3.1.17. (3aS*R*,8aR*S*)-5-Ethoxy-6-methoxy-2,3,3a,8atetrahydro-1,8-dioxa-cyclopenta[a]inden-4-ol, 45

$\mathrm{P}_{2} \mathrm{O}_{5}(1.98 \mathrm{~g}, 14 \mathrm{mmol})$ was added to a solution of phenol 44 (50 mg, $0.2 \mathrm{mmol}$ ) and ethyl 2-hydroxy-5-oxo-1-cyclopentene-1-carboxylate $^{36}(34 \mathrm{mg}, 0.2 \mathrm{mmol})$ in dry benzene $(10 \mathrm{~mL})$ and stirred at $17^{\circ} \mathrm{C}$ for $2 \mathrm{~h}$. The mixture was cooled to $0{ }^{\circ} \mathrm{C}$ and stirred for a further $2 \mathrm{~h}$. The mixture was warmed to $17^{\circ} \mathrm{C}$ and diluted with EtOAc $(10 \mathrm{~mL})$ and $10 \%$ aqueous $\mathrm{HCl}(5 \mathrm{~mL})$. The organic layer was separated and washed with saturated sodium bicarbonate $(5 \mathrm{~mL})$, dried $\left(\mathrm{MgSO}_{4}\right)$ and concentrated in vacuo. Initial crude ${ }^{1} \mathrm{H}$ NMR showed the phenol $\mathbf{4 4}$ and the title compound in a 2:3 ratio. Separation by column chromatography (flash silica $50 \%$ EtOAc/petrol) afforded the phenol $44(15 \mathrm{mg}, 30 \%)$ and the title compound 45, a microcrystalline solid (17 mg, 34\%, mp 117-120 ${ }^{\circ} \mathrm{C}$ ). $\nu_{\max }$ (film) $/ \mathrm{cm}^{-1} 3429$ (br), 2966 (s), 2924 (s), 2852 (s), 1629 (s), 1498 (s), 1462 (s), 1126 (s); ${ }^{1} \mathrm{H}$ NMR (300 MHz, $\left.\mathrm{CDCl}_{3}\right) \delta 6.35(1 \mathrm{H}, \mathrm{d}, J=5.4 \mathrm{~Hz}, \mathrm{H}-8 \mathrm{a}), 6.10(1 \mathrm{H}, \mathrm{s}, \mathrm{Ar} H)$, $5.90(1 \mathrm{H}, \mathrm{s}, \mathrm{OH}), 4.16-4.02\left(4 \mathrm{H}, \mathrm{m}, \mathrm{OCH}_{2} \mathrm{CH}_{3}, \mathrm{H}-2\right.$, $\mathrm{H}-3 \mathrm{a}), \quad 3.84$ (3H, s, OMe), 3.74-3.64 (1H, m, H-2), 2.30-2.12 (2H, m, H-3), $1.40\left(3 \mathrm{H}, \mathrm{t}, J=6.7 \mathrm{~Hz}, \mathrm{OCH}_{2} \mathrm{CH}_{3}\right)$; ${ }^{13} \mathrm{C}$ NMR $\left(75 \mathrm{MHz}, \mathrm{CDCl}_{3}\right) \delta 156.4,153.2,146.2,129.0$, $112.2,104.7,86.8,69.6,67.8,56.2,45.2,31.7,15.9 ; \mathrm{m} / \mathrm{z}$ (CI) $253\left(\mathrm{MH}^{+}, 100 \%\right)$, found $\mathrm{MH}^{+} 252.09929, \mathrm{C}_{13} \mathrm{H}_{16} \mathrm{O}_{5}$ requires $\mathrm{MH}^{+} 253.1071$.

\subsubsection{8. (3aS* $\left.R^{*}, 8 a R^{*} S^{*}\right)-6-$ Methoxy-2,3,3a,8a-tetrahydro- \\ 1,8-dioxa-cyclopenta[a]indene-4,7-dione, 47}

To a solution of phenol $44(161 \mathrm{mg}, 0.64 \mathrm{mmol})$ in $\mathrm{CH}_{3} \mathrm{CN}$ $(7 \mathrm{~mL})$ at $0{ }^{\circ} \mathrm{C}$ was added $\mathrm{CAN}$ (771 $\mathrm{mg}$ dissolved in water $4 \mathrm{~mL}, 1.4 \mathrm{mmol})$. The reaction mixture was stirred for $10 \mathrm{~min}$, followed by extraction with EtOAc $(2 \times 10 \mathrm{~mL})$ and water $(20 \mathrm{~mL})$. Purification of the residue by column chromatography (flash silica 50\% EtOAc/petrol) afforded a brown solid, which on recrystallization from EtOAc/hexane gave the title compound, an orange-coloured solid (86 mg, 61\%, $\mathrm{mp} 137-138{ }^{\circ} \mathrm{C}$ ). $\nu_{\max }$ (film) $/ \mathrm{cm}^{-1} 2988$ (s), 2947 (s), 2891 (s), 1695 (s), 1648 (s), 1589 (s); ${ }^{1} \mathrm{H}$ NMR (300 MHz, $\left.\mathrm{CDCl}_{3}\right) \delta 6.40(1 \mathrm{H}, \mathrm{d}, J=6.0 \mathrm{~Hz}, \mathrm{H}-8 \mathrm{a}), 5.72(1 \mathrm{H}, \mathrm{s}, \mathrm{H}-5)$, 4.20-4.13 (1H, m, H-2), 3.95-3.93 (1H, m, H-3a), 3.80 $(3 \mathrm{H}, \mathrm{s}, \mathrm{OMe}), 3.76-3.66(1 \mathrm{H}, \mathrm{m}, \mathrm{H}-2), 2.24-2.12(2 \mathrm{H}, \mathrm{m}$, $\mathrm{H}-3) ;{ }^{13} \mathrm{C} \mathrm{NMR}\left(75 \mathrm{MHz}, \mathrm{CDCl}_{3}\right) \delta 184.1,173.7,157.8$, 156.7, 121.6, 114.1, 107.3, 68.4, 57.0, 45.4, 30.5; m/z (CI) $222\left(\mathrm{M}^{+}, 40 \%\right)$, found $\mathrm{C} 59.84 \%, \mathrm{H} 4.47 \%, \mathrm{C}_{11} \mathrm{H}_{10} \mathrm{O}_{5}$ requires $\mathrm{C} 59.46 \%, \mathrm{H} 4.54 \%$.

\subsubsection{9. (3aS*R*,8aR* $\left.S^{*}\right)-6-$ Methoxy-2,3,3a,8a-tetrahydro- \\ 1,8-dioxa-cyclopenta[a]indene-4,7-diol, 48}

To a solution of quinone 47 (43 $\mathrm{mg}, 0.2 \mathrm{mmol}$ ) in methanol ( $5 \mathrm{~mL}$ ) was added $\mathrm{NaBH}_{4}(30 \mathrm{mg}, 0.8 \mathrm{mmol})$. The resulting solution was stirred at $17^{\circ} \mathrm{C}$ for $30 \mathrm{~min}$. Water $(15 \mathrm{~mL})$ was added and the organic layers extracted with EtOAc $(2 \times 20 \mathrm{~mL})$, dried $\left(\mathrm{MgSO}_{4}\right)$ and concentrated in vacuo. Purification by column chromatography (flash silica $50 \%$ EtOAc/petrol) afforded the title compound, a colourless oil (19.1 mg, $42 \%$ ). $\nu_{\max }\left(\right.$ film) $/ \mathrm{cm}^{-1} 3388$ (br), 2963 (s), 2885 (s), 1640 (s), 1592 (s), 1492 (s); ${ }^{1} \mathrm{H}$ NMR (300 MHz, $\left.\mathrm{CDCl}_{3}\right) \delta 6.28$
$(1 \mathrm{H}, \mathrm{d}, J=6.0 \mathrm{~Hz}, \mathrm{H}-8 \mathrm{a}), 6.07$ (1H, s, H-5), 5.43 (1H, br s, $\mathrm{OH}), 4.92(1 \mathrm{H}$, br s, OH), 4.18-4.00 (2H, m, H-2), $3.80(3 \mathrm{H}$, s, OMe), 3.78-3.60 (1H, m, H-3a), 2.30-2.12 (2H, m, H-3); $m / z$ (CI) $224\left(\mathrm{M}^{+}, 20 \%\right) 225\left(\mathrm{MH}^{+}, 100 \%\right)$, found $\mathrm{M}^{+}$ 224.0691, $\mathrm{C}_{11} \mathrm{H}_{12} \mathrm{O}_{5}$ requires 224.06847.

\subsubsection{0. (3aS*R*,8aR*S*)-5-(tert-Butyl-dimethylsilanyl)-6- methoxy-2,3,3a,8a-tetrahydro-1,8-dioxa-cyclo- penta[a]indene-4,7-dione, 50}

To a solution of phenol 40 (123 mg, $0.3 \mathrm{mmol})$ in $\mathrm{CH}_{3} \mathrm{CN}$ $(5 \mathrm{~mL})$ at $0{ }^{\circ} \mathrm{C}$ was added $\mathrm{CAN}(362 \mathrm{mg}$ dissolved in water $3 \mathrm{~mL}, 0.7 \mathrm{mmol})$. The reaction was stirred for $10 \mathrm{~min}$, followed by extraction with EtOAc $(2 \times 10 \mathrm{~mL})$ and water $(20 \mathrm{~mL})$. Purification by column chromatography (flash silica $20 \%$ EtOAc/petrol) afforded the title compound as a brown solid (102 mg, 93\%, mp 99-100 $\left.{ }^{\circ} \mathrm{C}\right) . \nu_{\max }($ film $) / \mathrm{cm}^{-1} 2949$ (s), 2927 (s), 2895 (s), 2854 (s), 1687 (s), 1656 (s), 1613 (s), $1548(\mathrm{~s}) ;{ }^{1} \mathrm{H}$ NMR $\left(300 \mathrm{MHz}, \mathrm{CDCl}_{3}\right) \delta 6.40(1 \mathrm{H}, \mathrm{d}$, $J=6.0 \mathrm{~Hz}, \mathrm{H}-8 \mathrm{a}), 4.24-4.15(1 \mathrm{H}, \mathrm{m}, \mathrm{H}-2), 3.98(3 \mathrm{H}, \mathrm{s}$, $\mathrm{OMe}), 3.96-3.88$ (1H, m, H-3a), 3.78 (1H, m, H-2), 2.25-2.15 (2H, m, H-3), $0.90\left(9 \mathrm{H}, \mathrm{s}, \mathrm{Si}-\mathrm{C}\left(\mathrm{CH}_{3}\right)_{3}\right), 0.28$ $\left(6 \mathrm{H}, \mathrm{s}, \mathrm{Si}\left(\mathrm{CH}_{3}\right)_{2}\right) ;{ }^{13} \mathrm{C} \mathrm{NMR}\left(75 \mathrm{MHz}, \mathrm{CDCl}_{3}\right) \delta$ 188.6, $175.0,164.7,156.5,129.4,122.6,114.0,68.4,68.2,61.2$, $45.9,30.5,30.0,27.3,27.0,25.9,18.0,14.4,-2.4 ; \mathrm{m} / \mathrm{z}(\mathrm{CI})$ $337\left(\mathrm{MH}^{+}, 40 \%\right), 354\left(\mathrm{MNH}_{4}^{+}, 10 \%\right)$, found $\mathrm{C} 61.40 \%, \mathrm{H}$ $7.77 \%, \mathrm{C}_{17} \mathrm{H}_{24} \mathrm{O}_{5} \mathrm{Si}$ requires $\mathrm{C} 60.69 \%, \mathrm{H} 7.19 \%$.

\subsubsection{1. (3aS*R*,8aR*S*)-5-(tert-Butyl-dimethyl-silanyl)-6-} methoxy-2,3,3a,8a-tetrahydro-1,8-dioxa-cyclopenta[a]indene-4,7-diol, 51

Quinone 50 (175 mg, $0.48 \mathrm{mmol}$ ) was dissolved in EtOAc $(8 \mathrm{~mL})$. To the reaction vessel was added $\mathrm{Pd} / \mathrm{C}(17.5 \mathrm{mg}$, $10 \% \mathrm{w} / \mathrm{w})$, the vessel was evacuated and refilled with an atmosphere of hydrogen. The flask was kept under a slight positive pressure of hydrogen (balloon) for a further period of $1.5 \mathrm{~h}$ at $17^{\circ} \mathrm{C}$ and then filtered through a pad of Celite (EtOAc)-CARE! The excess solvent was removed in vacuo to afford the title compound as an amorphous white solid (175 mg, essentially quantitative yield). $\nu_{\max }($ film $) / \mathrm{cm}^{-1}$ 3407 (br), 2952 (s), 2930 (s), 2890 (s), 2855 (s), 1607 (s); ${ }^{1} \mathrm{H}$ NMR $\left(300 \mathrm{MHz}, \mathrm{CDCl}_{3}\right) \quad \delta \quad 6.42(1 \mathrm{H}, \mathrm{d}, J=5.7 \mathrm{~Hz}$, H-8a), 5.02 (1H, br s, OH), 4.78 (1H, br s, OH), 4.20-4.12 (1H, m, H-2), 4.10-4.00 (1H, m, H-3a), 3.83 (3H, s, OMe), 3.80-3.70 (1H, m, H-2), 2.26-2.16 (2H, m, H-3), $0.94(9 \mathrm{H}$, s, $\left.\mathrm{Si}-\mathrm{C}\left(\mathrm{CH}_{3}\right)_{3}\right), 0.44\left(3 \mathrm{H}, \mathrm{s}, \mathrm{SiCH}_{3}\right), 0.42\left(3 \mathrm{H}, \mathrm{s}, \mathrm{SiCH}_{3}\right)$; ${ }^{13} \mathrm{C}$ NMR $\left(75 \mathrm{MHz}, \mathrm{CDCl}_{3}\right) \delta 153.7,150.2,150.1,126.9$, $113.2,109.6,106.5,68.1,60.9,45.6,31.5,27.1,18.6$, $-1.56,-1.61 ; \mathrm{m} / \mathrm{z}$ (CI) $338\left(\mathrm{M}^{+}, 20 \%\right), 339\left(\mathrm{MH}^{+}, 70 \%\right)$, found $\mathrm{M}^{+} 338.15433, \mathrm{C}_{17} \mathrm{H}_{26} \mathrm{O}_{5} \mathrm{Si}$ requires $\mathrm{M}^{+} 338.1544$.

\subsubsection{2. (3aS* $\left.R^{*}, 8 a R^{*} S^{*}\right)$-4-(tert-Butyl-dimethyl-silanyl- oxy)-6-methoxy-2,3,3a,8a-tetrahydro-1,8-dioxa-cyclo- penta[a]inden-7-ol, 52}

A solution of the hydroquinone $51(175 \mathrm{mg}, 0.54 \mathrm{mmol})$ in degassed toluene $(20 \mathrm{~mL})$ was brought to reflux under nitrogen. After $1 \mathrm{~h}$ the reaction was cooled to ambient temperature and the solvent removed in vacuo to afford the title compound 
as an oil (175 mg, essentially quantitative yield). $\nu_{\max }$ (film)/ $\mathrm{cm}^{-1} 3544$ (br), 2958 (s), 2931 (s), 2859 (s); ${ }^{1} \mathrm{H}$ NMR $\left(300 \mathrm{MHz}, \mathrm{CDCl}_{3}\right) \delta 6.36(1 \mathrm{H}, \mathrm{d}, J=5.7 \mathrm{~Hz}, \mathrm{H}-8 \mathrm{a}), 5.98$ $(1 \mathrm{H}, \mathrm{s}, \mathrm{H}-5), 5.02(1 \mathrm{H}, \mathrm{br} \mathrm{s}, \mathrm{OH}), 4.08(1 \mathrm{H}, \mathrm{br} \mathrm{t}, J=7.8 \mathrm{~Hz}$, $\mathrm{H}-2), 4.00-3.94(1 \mathrm{H}, \mathrm{m}, \mathrm{H}-3 \mathrm{a}), 3.84$ (3H, s, OMe), 3.76$3.66(1 \mathrm{H}, \mathrm{m}, \mathrm{H}-2), 2.30-2.08(2 \mathrm{H}, \mathrm{m}, \mathrm{H}-3), 1.04(9 \mathrm{H}, \mathrm{s}$, $\left.\mathrm{Si}-\mathrm{C}\left(\mathrm{CH}_{3}\right)_{3}\right), 0.28\left(3 \mathrm{H}, \mathrm{s}, \mathrm{SiCH}_{3}\right), 0.22\left(3 \mathrm{H}, \mathrm{s}, \mathrm{SiCH}_{3}\right) ;{ }^{13} \mathrm{C}$ NMR $\left(75 \mathrm{MHz}, \mathrm{CDCl}_{3}\right) \delta 148.1,147.2,144.5,124.5,112.6$, $111.4,96.7,67.8,56.7,45.7,31.9,25.9,18.3,-3.7,-4.1$; $\mathrm{m} / \mathrm{z}$ (CI) $338\left(\mathrm{M}^{+}, 10 \%\right), 339\left(\mathrm{MH}^{+}, 100 \%\right)$, found $\mathrm{M}^{+}$ $338.15415, \mathrm{C}_{17} \mathrm{H}_{26} \mathrm{O}_{5} \mathrm{Si}$ requires $\mathrm{M}^{+} 338.1544$.

\subsubsection{3. (3aS* $\left.R^{*}, 8 a R^{*} S^{*}\right)$-4-(tert-Butyldimethylsilanyloxy)- 6-methoxy-2,3,3a,8a-tetrahydro-1,8-dioxa-cyclo- penta[a]inden-7-yl trifluoromethanesulfonate, 53}

To a solution of the phenol $\mathbf{5 2}(75 \mathrm{mg}, 0.2 \mathrm{mmol})$ in dry DCM $(1 \mathrm{~mL})$ at $0{ }^{\circ} \mathrm{C}$ was added DMAP $(1.3 \mathrm{mg}, 0.01 \mathrm{mmol}$, $5 \%)$, pyridine $(1 \mathrm{~mL})$ followed by triflic anhydride $(70 \mu \mathrm{L}$, $0.4 \mathrm{mmol})$. The resultant solution was stirred at $0{ }^{\circ} \mathrm{C}$ for $1 \mathrm{~h}$ and then quenched by the addition of water $(5 \mathrm{~mL})$. The aqueous layer was extracted with ether $(3 \times 5 \mathrm{~mL})$ and the combined organic fractions were washed with $1 \mathrm{M} \mathrm{HCl}(20 \mathrm{~mL})$ and brine $(2 \times 20 \mathrm{~mL})$, dried $\left(\mathrm{MgSO}_{4}\right)$ and concentrated in vacuo. Purification by column chromatography (flash silica $20 \%$ EtOAc/petrol) afforded the title compound as an amorphous white solid $(87 \mathrm{mg}, 93 \%) . \nu_{\max }\left(\right.$ film) $/ \mathrm{cm}^{-1} 2956(\mathrm{~s})$, 2934 (s), 2889 (s), 2859 (s), 1632 (s), 1605 (s); ${ }^{1} \mathrm{H}$ NMR $\left(300 \mathrm{MHz}, \mathrm{CDCl}_{3}\right) \delta 6.43(1 \mathrm{H}, \mathrm{d}, J=5.7 \mathrm{~Hz}, \mathrm{H}-8 \mathrm{a}), 6.00$ $(1 \mathrm{H}, \mathrm{s}, \mathrm{H}-5), 4.18-4.10(1 \mathrm{H}, \mathrm{m}, \mathrm{H}-2), 4.02-3.94(1 \mathrm{H}, \mathrm{m}$, $\mathrm{H}-3 \mathrm{a}), 3.86(3 \mathrm{H}, \mathrm{s}, \mathrm{OMe}), 3.74-3.64(1 \mathrm{H}, \mathrm{m}, \mathrm{H}-2), 2.25-$ $2.15(2 \mathrm{H}, \mathrm{m}, \mathrm{H}-3), 1.05\left(9 \mathrm{H}, \mathrm{s}, \mathrm{Si}-\mathrm{C}\left(\mathrm{CH}_{3}\right)_{3}\right), 0.33(3 \mathrm{H}, \mathrm{s}$, $\left.\mathrm{SiCH}_{3}\right), 0.29\left(3 \mathrm{H}, \mathrm{s}, \mathrm{SiCH}_{3}\right) ;{ }^{19} \mathrm{~F}$ NMR $(\mathrm{TFA}=0) \delta-74(\mathrm{~s}$, $\left.\mathrm{CF}_{3}\right) ;{ }^{13} \mathrm{C}$ NMR $\left(75 \mathrm{MHz}, \mathrm{CDCl}_{3}\right) \delta 153.0,152.5,151.3$, 119 (q, $\left.J=284 \mathrm{~Hz}, C \mathrm{~F}_{3}\right), 113.4,111.3,96.3,67.6,56.4,45.2$, $31.5,25.5,18.0,-4.0,-4.2 ; \mathrm{m} / \mathrm{z}$ (CI) $470\left(\mathrm{M}^{+}, 3 \%\right), 471$ $\left(\mathrm{MH}^{+}, 5 \%\right), 489\left(\mathrm{MNH}_{4}^{+}, 10 \%\right)$, found $\mathrm{M}^{+}$470.10496, $\mathrm{C}_{18} \mathrm{H}_{25} \mathrm{O}_{7} \mathrm{~F}_{3} \mathrm{SSi}$ requires $\mathrm{M}^{+} 470.1037$.

\subsubsection{4. (3a $\left.S^{*} R^{*}, 8 a R^{*} S^{*}\right)-6-$ Methoxy-2,3,3a,8a-tetrahydro- 1,8-dioxa-cyclopenta[a]inden-4-ol, $\mathbf{2 6}^{20}$ (Method A)}

To a solution of triflate $53(96 \mathrm{mg}, 0.2 \mathrm{mmol})$ in DMF $(2 \mathrm{~mL})$ was added tributylamine $(0.19 \mathrm{~mL}, 0.8 \mathrm{mmol})$, 1,3-bis(di-phenylphosphino)propane $\quad(14 \mathrm{mg}, \quad 0.03 \mathrm{mmol})$, $\mathrm{PdCl}_{2}\left(\mathrm{PPh}_{3}\right)_{2}(5 \mathrm{mg}, 0.02 \mathrm{mmol})$ and formic acid $(100 \mu \mathrm{L})$. The resulting mixture was heated to $80-90{ }^{\circ} \mathrm{C}$ and stirred for $18 \mathrm{~h}$. The solution was cooled and water and ether $(15 \mathrm{~mL})$ were added. The organic layer was washed with $1.0 \mathrm{M} \mathrm{HCl}(20 \mathrm{~mL})$, dried $\left(\mathrm{MgSO}_{4}\right)$ and concentrated in vacuo to afford the title compound contaminated with $N, N$-dibutylformamide. Recrystallization from $\mathrm{CCl}_{4}$ afforded the title compound as a white solid $\left(5 \mathrm{mg}, 12 \%, \mathrm{mp} 148-150{ }^{\circ} \mathrm{C}\right.$, lit. ${ }^{20 \mathrm{~b}, \mathrm{c}}$ $152-153^{\circ} \mathrm{C}$ ). $\nu_{\max }(\mathrm{film}) / \mathrm{cm}^{-1} 3353$ (br), 2954 (s), 2917 (s), 2848 (s), 2848 (s), 1625 (s), 1443 (s); ${ }^{1} \mathrm{H}$ NMR (300 MHz, $\left.\mathrm{CDCl}_{3}\right) \delta 6.31(1 \mathrm{H}, \mathrm{d}, J=5.7 \mathrm{~Hz}, \mathrm{H}-8 \mathrm{a}), 6.03(1 \mathrm{H}, \mathrm{d}$, $J=1.8 \mathrm{~Hz}, \mathrm{Ar}-\mathrm{H}), 5.90(1 \mathrm{H}, \mathrm{d}, J=1.8 \mathrm{~Hz}, \mathrm{Ar}-\mathrm{H}), 4.80(1 \mathrm{H}$, br s, OH), 4.11-4.04 $(1 \mathrm{H}, \mathrm{m}, \mathrm{H}-2), 4.01-3.94(1 \mathrm{H}, \mathrm{m}, \mathrm{H}-$ 3a), $3.70(3 \mathrm{H}, \mathrm{s}, \mathrm{OMe}), 3.68-3.60(1 \mathrm{H}, \mathrm{m}, \mathrm{H}-2), 2.20-2.07$
$(2 \mathrm{H}, \mathrm{m}, \mathrm{H}-3) ;{ }^{13} \mathrm{C}$ NMR $\left(75 \mathrm{MHz}, \mathrm{CDCl}_{3}\right) \delta 160.3,160.2$, $150.9,110.4,103.8,93.3,87.0,65.9,54.0,42.5,29.9 ; \mathrm{m} / \mathrm{z}$ (CI) $208 \quad\left(\mathrm{M}^{+}, 20 \%\right), 209\left(\mathrm{MH}^{+}, 100 \%\right)$, found $\mathrm{M}^{+}$ 208.07345, $\mathrm{C}_{11} \mathrm{H}_{12} \mathrm{O}_{4}$ requires $\mathrm{M}^{+} 208.0736$.

\subsubsection{5. (3aS* $\left.R^{*}, 8 a R^{*} S^{*}\right)$-6-Methoxy-2,3,3a,8a-tetrahydro- \\ 1,8-dioxa-cyclopenta[a]inden-4-ol, $\mathbf{2 6}^{20}$ (Method B)}

To solution of triflate $\mathbf{5 3}(19 \mathrm{mg}, 0.04 \mathrm{mmol})$ in methanol $(1 \mathrm{~mL})$ was added Raney nickel $(50 \%$ slurry in water $(0.4 \mathrm{~mL}$, settled volume)) that had been previously rinsed with methanol (CARE) and the mixture stirred for $12 \mathrm{~h}$ under nitrogen at ambient temperature. The mixture was passed through a pad of Celite to remove the Raney nickel (CARE) and the solution concentrated in vacuo to give an inseparable mixture of the triflate $\mathbf{5 3}$ and silyl ether $\mathbf{5 4}$ in a 4:3 ratio $(9 \mathrm{mg}$, yield for mixture). TBAF ( $30 \mu \mathrm{L}, 1 \mathrm{M}$ in THF, $0.03 \mathrm{mmol}$ ) was added to the mixture $(9 \mathrm{mg}, 0.03 \mathrm{mmol})$ in THF $(2 \mathrm{~mL})$ and the solution stirred for $20 \mathrm{~min}$ at $17{ }^{\circ} \mathrm{C}$. Water was added and the organic layers extracted with ether $(2 \times 10 \mathrm{~mL})$, dried $\left(\mathrm{MgSO}_{4}\right)$ and concentrated in vacuo. Purification by column chromatography (flash silica 20\% EtOAc/petrol) afforded the phenol 26 (3 $\mathrm{mg}, 38 \%$ over 2 steps), whose spectral data were identical with that reported above.

\section{Acknowledgements}

We thank Sanofi-Synthélabo (S.A.E.), Zeneca Specialties (J.E.P.) for the provision of CASE awards and the EPSRC (S.P.I. and M.R.H.) for postgraduate studentships (GR/K/ 16197).

\section{References and notes}

1. Donohoe, T. J. Synlett 2002, 1223.

2. Schrock, R. R. J. Organomet. Chem. 1986, 300, 249.

3. Kingston, D. G. I.; Newman, D. J. Curr. Opin. Drug Discov. Devel. 2007, $10,130$.

4. Semmelhack, M. F. Organometallics in Organic Synthesis: A Manual, 2nd ed.; Schlosser, M., Ed.; Wiley: Chichester, UK, 2002; Chapter 9, pp 1024-1042.

5. Dötz, K. H. Angew. Chem. 1975, 87, 672; For reviews see: Dötz, K. H.; Tomuschat, P. Chem. Soc. Rev. 1999, 28, 187; de Meijere, A.; Schirmer, H.; Duetsch, M. Angew. Chem., Int. Ed. 2000, 39, 3964; Dötz, K. H.; Stendel, J. Modern Arene Chemistry; Astruc, D., Ed.; Wiley-VCH Verlag GmbH \& Co. KgaA: Weinheim, Germany, 2002.

6. King, J.; Quayle, P.; Malone, J. F. Tetrahedron Lett. 1990, 31, 5221.

7. Dötz, K. H.; Muhlemeier, J.; Schubert, U.; Orama, O. J. Organomet. Chem. 1983, 247, 187; Yamashita, A.; Toy, A. Tetrahedron Lett. 1986, 27, 3471 .

8. Wulff, W. D.; Tang, P. C.; McCullum, J. S. J. Am. Chem. Soc. 1981, 103, 7677 .

9. For a preliminary account of this work see: Eastham, S. A.; Ingham, S. P.; Hallett, M. R.; Herbert, J.; Quayle, P.; Raftery, J. Tetrahedron Lett. 2006, 47, 2299.

10. For related applications to steroidal systems see: King, J. D.; Quayle, P. Tetrahedron Lett. 1991, 32, 7759; For subsequent studies into stereochemical issues see: Beddoes, R. L.; King, J. D.; Quayle, P. Tetrahedron Lett. 1995, 36, 3027.

11. Eastham, S. A.; Herbert, J.; Painter, J. E.; Patel, P.; Quayle, P. Synlett 1998, 61. 
12. White, J. D.; Smits, H. Org. Lett. 2005, 7, 235; Barluenga, J.; Vicente, R.; López, L. A.; Rubio, E.; Tomás, M. J. Am. Chem. Soc. 2004, 126, 5975; Barluenga, J.; Vicente, R.; López, L. A.; Rubio, E.; Tomás, M.; ÁlvarezRúa, C. J. Am. Chem. Soc. 2004, 126, 470; Barluenga, J.; Aznar, F.; Gutiérrez, I.; Martin, J. A. Org. Lett. 2002, 4, 2719; Dötz, K. H.; Otto, F.; Nieger, M. J. Organomet. Chem. 2001, 621, 77; Waters, M. L.; Brandvold, T. A.; Isaacs, L.; Wulff, W. D.; Rheingold, A. L. Organometallics 1998, 17, 4298; Chan, K. S.; Zhang, H. Synth. Commun. 1995, 25, 635; Harvey, D. F.; Grenzer, E. M.; Gantzel, P. K. J. Am. Chem. Soc. 1994, 116, 6719; Wulff, W. D.; Bax, B. M.; Brandvold, T. A.; Chan, K. S.; Gilbert, A. M.; Hsung, R. P.; Mitchell, J.; Clardy, J. Organometallics 1994, 13, 102; Brandvold, T. A.; Wulff, W. D.; Rheingold, A. L. J. Am. Chem. Soc. 1990, 112, 1645; Chan, K. S.; Peterson, G. A.; Brandvold, T. A.; Faron, K. L.; Challener, C. A.; Hyldahl, C.; Wulff, W. D. J. Organomet. Chem. 1987, 334, 9; Wulff, W. D.; Chan, K. S.; Tang, P. C. J. Org. Chem. 1984, 49, 2293.

13. (a) Boeckman, R. K.; Bruza, K. J. Tetrahedron Lett. 1977, 18, 4187; Boeckman, R. K.; Bruza, K. J. Tetrahedron 1981, 37, 3997; Metallation of cyclic vinyl ethers can be capricious, see: Milne, J. E.; Kocienski, P. J. Synthesis 2003, 584 for reviews see: Chinchilla, R.; Najera, C.; Yus, M. Chem. Rev. 2004, 104, 2667; Friesen, R. W. J. Chem. Soc., Perkin Trans. 1 2001, 1969. Metallation of dihydrofurans with this oxygenation pattern has little precedent, see: Boeckman, R. K.; Jayaram, R.; Johnston, B. H. Heterocycles 1987, 25, 33; Schreiber, S. L.; Porco, J. A. J. Org. Chem. 1989, 54, 4721; (b) Quayle, P. Comprehensive Organic Functional Group Transformations; Moody, C. J., Ed.; Pergamon: Oxford, 1995; Vol. 5, Chapter 25, pp 931-960; Timko, J. M.; Yamashita, A. Org. Synth. 1993, 71,72 .

14. Harrity, J. P. A.; Kerr, W. J.; Middlemiss, D. Tetrahedron Lett. 1993, 34, 2995.

15. This analysis was based upon a single precedent, see: Dötz, K. H.; Glaenzer, J. J. Chem. Soc., Chem. Commun. 1993, 1036.

16. (a) Hallett, M. R.; Painter, J. E.; Ricketts, D.; Patel, P.; Quayle, P. Tetrahedron Lett. 1998, 39, 2851; (b) Painter, J. E.; Quayle, P.; Patel, P. Tetrahedron Lett. 1995, 36, 8089; (c) Boyd, E.; Jones, R. V. H.; Quayle, P.; Waring, A. J. Tetrahedron Lett. 2006, 47, 7983.

17. (a) Beddoes, R. L.; Painter, J. E.; Quayle, P.; Patel, P. Tetrahedron Lett. 1996, 37, 9385; (b) Beddoes, R. L.; Painter, J. E.; Quayle, P.; Patel, P. Tetrahedron 1997, 53, 17297.

18. Boyd, E.; Hallett, M.; Jones, R. V. H.; Painter, J. E.; Patel, P.; Quayle, P.; Waring, A. J. Tetrahedron Lett. 2006, 47, 8337.

19. Eastham, S. E.; Herbert, J.; Quayle, P. Unpublished work.

20. (a) Zhou, G.; Corey, E. J. J. Am. Chem. Soc. 2005, 127, 11958; (b) Noland, W. E.; Kedrowski, B. L. Org. Lett. 2000, 2, 2109; (c) Catellino, A.; Rapoport, H. J. Org. Chem. 1986, 51, 1006; (d) Shisido, K.; Bando, T. J. Mol. Catal. B: Enzym. 1998, 5, 183; (e) Bando, T.; Shisido, K. Synlett 1997, 665; (f) Pirrung, M. C.; Lee, Y. R. Tetrahedron Lett. 1996, 37, 2391; (g) Koreeda, M.; Dixon, L. A.; Hsi, J. D. Synlett 1993, 556; (h) Horne, S.; Weeratunga, G.; Rodrigo, R. J. Chem. Soc., Chem. Commun. 1990, 39; (i) Weeratunga, G.; Horne, S.; Rodrigo, R. J. Chem. Soc., Chem.
Commun. 1988, 721; (j) Roberts, J. C.; Sheppard, A. H.; Knight, J. A.; Roffey, P. J. Chem. Soc. C 1968, 22.

21. See: Harrity, J. P. A.; Kerr, W. J.; Middlemiss, D.; Scott, J. S. J. Organomet. Chem. 1997, 532, 219 and references therein. For surrogates see: Anderson, J. C.; Denton, R. M.; Hickin, H. G.; Wilson, C. Tetrahedron 2004, 60, 2327.

22. Previous syntheses of this compound ((a) Malanga, C.; Mannuci, S.; Lardicci, L. J. Chem. Res., Synop. 2001, 97; (b) Brunetière, A. P.; Lallemand, J. Y. Tetrahedron Lett. 1988, 29, 2179; (c) Pezechk, M.; Brunetière, A. P.; Lallemand, J. Y. Tetrahedron Lett. 1986, 27, 3715) were not wholly amenable to scale-up.

23. Bamford, W. R.; Stevens, R. R. J. Chem. Soc. 1952, 4735; For related applications see: (a) Gianturco, M. A.; Friedel, P.; Flanagan, V. Tetrahedron Lett. 1965, 6, 1847; (b) Brunetière, A. P.; Leclaire, M.; Bhatnagar, S.; Lallemand, J. Y.; Cossy, J. Tetrahedron Lett. 1989, 30, 341; (c) Smith, A. B.; Sulikowski, G. A.; Fujimoto, K. J. Am. Chem. Soc. 1989, 111, 8039.

24. See: Dulcère, J.-P.; Crandall, J.; Faure, R.; Santelli, M.; Agati, V.; Mihoubi, M. N. J. Org. Chem. 1993, 58, 5702 and references therein.

25. cf. Ghosh, A. K.; Kincaid, J. F.; Walters, D. E.; Chen, Y.; Chaudhuri, N. C.; Thompson, W. J.; Culberson, C.; Fitzgerald, P. M. D.; Lee, H. Y.; McKee, S. P.; Munson, P. M.; Duong, T. T.; Darke, P. L.; Zugay, J. A.; Schleif, W. A.; Axel, M. G.; Lin, J.; Huff, J. R. J. Med. Chem. 1996, $39,3278$.

26. Okabe, M.; Abe, M.; Tada, M. J. Org. Chem. 1982, 47, 1775.

27. This is a modification of the procedure developed by Raucher: Raucher, S.; Bray, B. L. J. Org. Chem. 1987, 52, 2332.

28. For a related reaction see: Hessler, E. J.; Van Rheenan, V. H. Chem. Abstr. 1980, $92,215642$.

29. For a preliminary discussion concerning the mechanism of these transformations see: Eastham, S. A.; Herbert, J.; Ingham, S. P.; Quayle, P.; Wolfendale, M. Tetrahedron Lett. 2006, 47, 6627.

30. Sethna, S. M.; Shah, N. M. Chem. Rev. 1945, 36, 1.

31. For related rearrangements during Dötz reactions see: (a) Moser, W. H.; Sun, L.; Huffman, J. C. Org. Lett. 2001, 3, 3389; (b) Fogel, L.; Hsung, R. P.; Wulff, W. D.; Sommer, R. D.; Rheingold, A. L. J. Am. Chem. Soc. 2001, 123, 5580; (c) Chamberlin, S.; Wulff, W. D. J. Org. Chem. 1994, 59, 3047.

32. Other workers have noted silatropic rearrangements in polysilylated phenols: (a) Muslin, D. V.; Lyapina, N. S.; Tyulina, N. E.; Khorshev, S. Y.; Vavilina, N. N. Zh. Obshch. Khim. 2001, 71, 1322; (b) Cooper, G. D. J. Org. Chem. 1961, 26, 925; Speier, J. L. J. Am. Chem. Soc. 1952, 73, 1003; For a review of Brook-type rearrangements see: Moser, W. H. Tetrahedron 2001, 57, 2065. This methodology has not apparently been developed further.

33. Saá, J. M.; Dopico, M.; Martorell, G.; García-Raso. J. Org. Chem. 1990, $55,991$.

34. Cacchi, S.; Ciattini, P. G.; Morera, E.; Ortar, G. Tetrahedron Lett. 1986, $27,5541$.

35. Disley, S. P. M.; Grime, R. W.; McInnes, E. J. L.; Spencer, D. M.; Swainston, N.; Whiteley, M. W. J. Organomet. Chem. 1998, 566, 151.

36. Büchi, G.; Roberts, E. C. J. Org. Chem. 1968, 33, 460. 